\title{
Are Free Trade Agreements Contagious?
}

\author{
Richard Baldwin \\ Dany Jaimovich* \\ Graduate Institute, Geneva
}

Preliminary. Please do not cite.

This version: 14 November 2008

\begin{abstract}
This paper presents empirical evidence on the extent to which FTAs are "contagious", using empirical techniques inspired by the study of contagion in exchange rate crises. Using different econometric techniques, it tests the null hypothesis that the signing of an FTA between one nation's trade partners has no affect on the probability of the nation signing a new FTA. The hypothesis is tested against other political, economical and geographical determinants of the FTA formation previously stated in the literature, finding evidence that the contagion phenomenon is present in different specifications and samples.
\end{abstract}

*Corresponding author: Dany Jaimovich, Avenue de la Paix 11A, 1202 Geneva, Switzerland, dany.jaimovich@graduateinstitute.ch. We would like to thanks the useful comments and suggestions we received during presentations at the Swiss Trade Economist Cooperative (Champex), The Graduate Institute, Geneva, and Geneva Trade and Development Workshop (WTO). 


\section{INTRODUCTION}

Free trade agreements (FTA) are being signed at a rapid pace. A central question for the trade system is: Why is bilateralism and regionalism spreading so rapidly? Some, starting with Krugman (1991a), link the spread of regionalism to slow progress in multilateral talks, a view recently embraced by Bhagwati (2008).

While this correlation between slow multilateralism and fast regionalism is intuitively appealing in recent years and for the years preceding the 1994 Uruguay Round agreement, it does not square well with data over a longer period. Over the past two decades, the pace of regionalism is not closely tied to the ebb and flow of multilateral talks. As the raw numbers in Figure 1 show, it is not clear that the number of deals accelerated when multilateral talks stalled between 1990 and 1994. Indeed it seems that the trend picked up just after the Uruguay Round agreement was struck in 1994. Likewise, the recent problems with the on-going Doha talks coincide with a slight decline in the rate of growth.

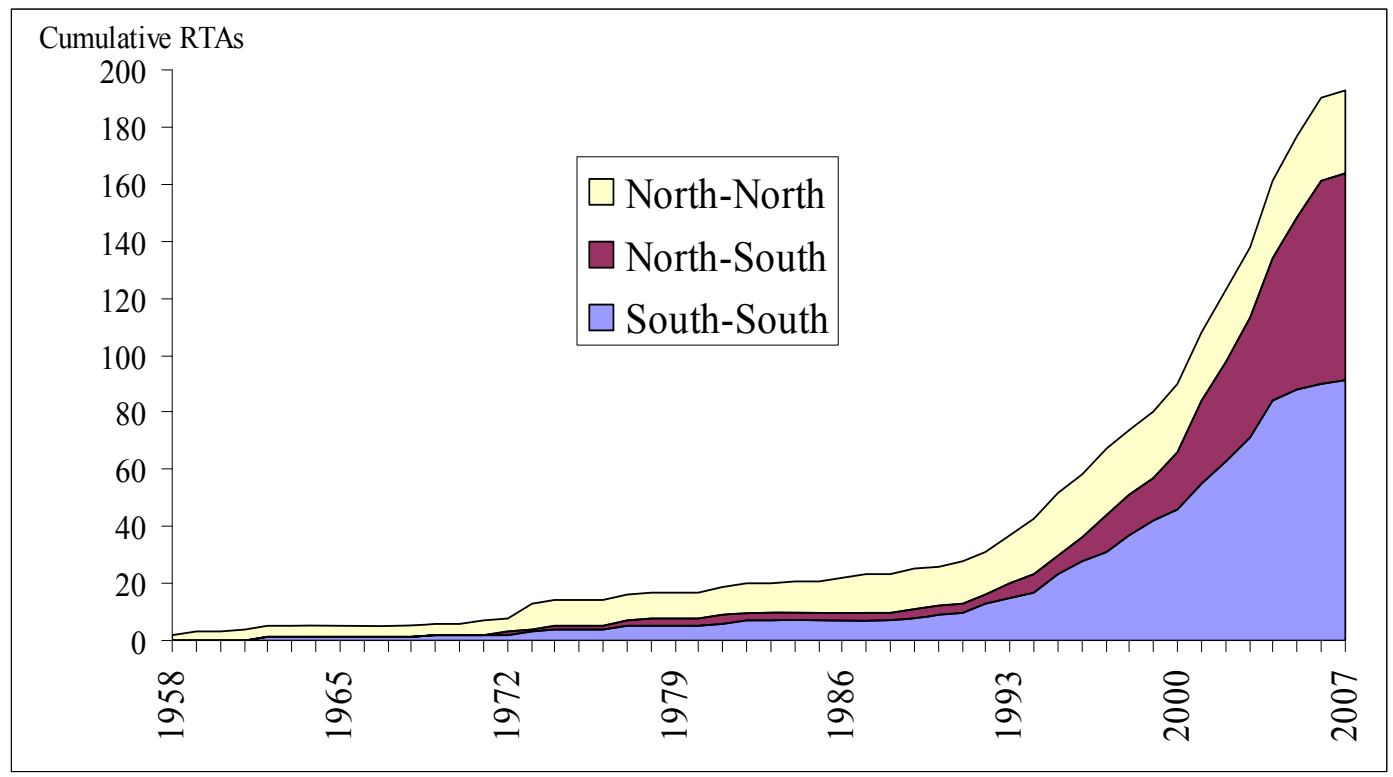

Figure 1: Explosion of FTAs, North-North, North-South and South-South, 1958-2007

Source: WTO RTA database, www.wto.org.

The Krugman-Bhagwati explanation also has little to say about the clear geographical pattern in new agreements. As Figure 2 shows, the spread of regionalism is far from homogenous across regions. Before 1976, Europe dominated, in the 1976-1990 period, the Americas dominated and in 1991-1999, the Former Soviet bloc nations dominated. Plainly, a global-wide explanation does not account for this regional variation in an obvious manner. This regional pattern suggests contagion - much like the spread of financial crisis. 
FTA regional waves: Distribution of new FTAs by region over time

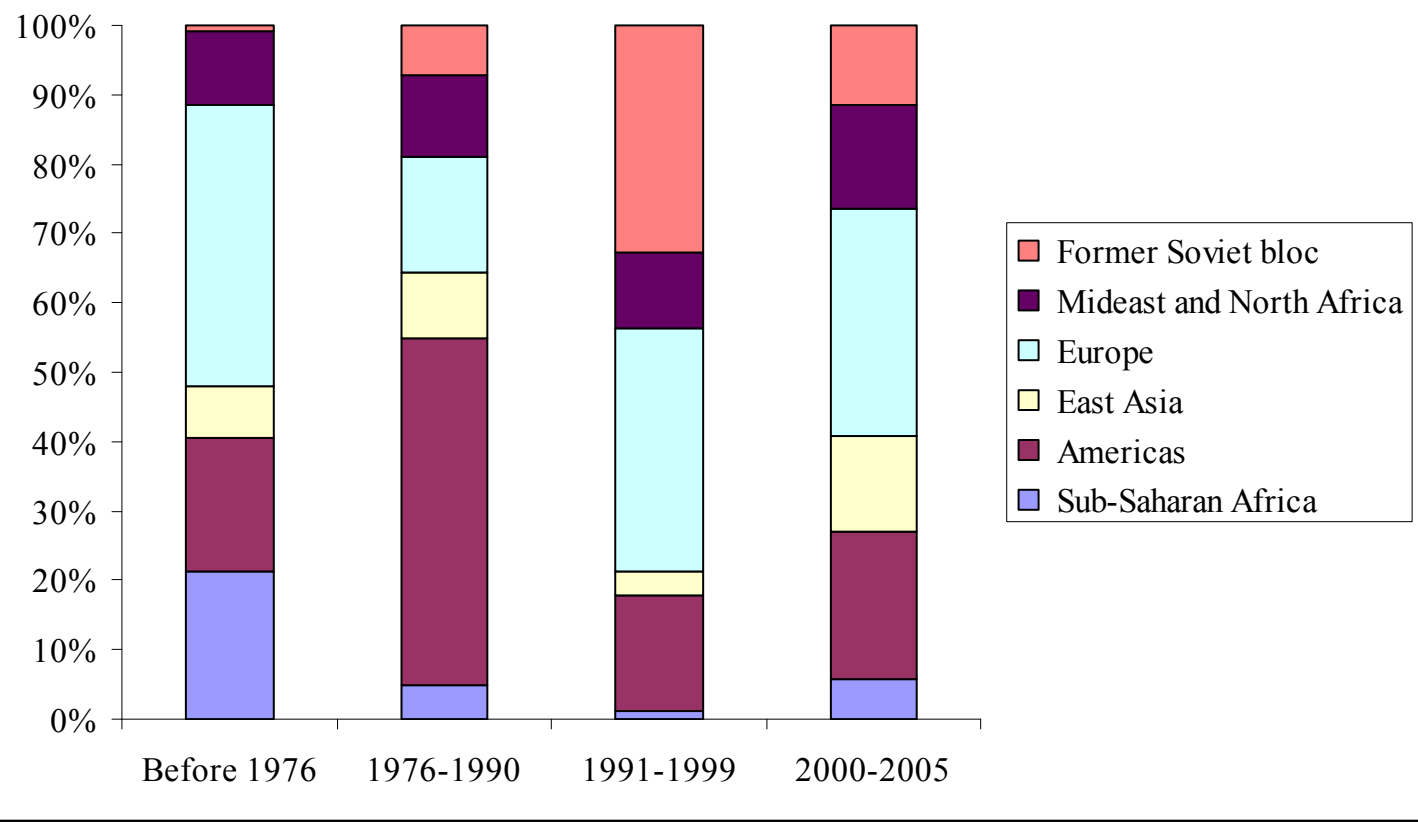

Figure 2: Geographic pattern of FTAs: Region-specific waves

This paper improve previous studies on the determinants of FTA introducing empirical techniques similar to the used to identify the transmission channels of financial crisis contagion, finding that there is evidence of "contagion effect" in the proliferation of FTA in recent years.

The rest of the paper is organized in three sections. The next section, Section 2, briefly reviews the theoretical frameworks that inform our empirics and summarizes relevant literature. Section 3 describes the unprecedented dataset of FTA that we will use and our measure of contagion. In Section 4 we present the main results of the empirical analysis in both a cross sectional and a panel data framework and the respective robustness checks. The final section contains our concluding remarks.

\section{THEORETICAL CONSIDERATIONS AND RELEVANT LITERATURE}

\subsection{Theoretical considerations}

Our empirical analysis focuses on the domino theory of regionalism (Baldwin 1993, 1995, 1997). The basic idea has two parts. First, trade diversion, or the threat of it, creates de novo political economy urges in third nations. These new forces favour pro-FTA forces and thus may tilt the balance towards a "yes" decision in nations that previously found it politically optimal to abstain. This is the first-round effect. The second round comes if new nations actually sign new FTAs as this then increases the threat of trade diversion on third nations. That is, the signing of agreements creates a sort of political economy momentum that can make it seem that FTAs are 'contagious', spreading like wildfire as it were.

The idea underlying the domino mechanism is an old one. A version can be distilled from the account in Chapter 5 of Viner (1950) of how dozens of German principalities and city-states were cajoled and coerced into joining Prussia's Zollverien. Whalley (1993) also views Western Hemispheric regionalism 
as largely defensive (rather than US-led). He, however, focuses on fears of US protectionism instead of trade diversion, and he does not posit a circular causality between bloc size and the strength of inclusionary pressures. Hufbauer (1989) uses the term "FTA magnetism" which captures the first step (idiosyncratic deepening sparks membership requests) but does not relate the strength of the magnetism to the bloc size. The formal model of the domino theory of regionalism was first presented in Baldwin (1993a) which was published as Baldwin (1995) ${ }^{1}$. Winters (1996) and Lawrence (1996) surveys regionalism and multilateralism models, putting the domino theory in perspective.

The main alternate hypotheses are: 1) the FTA-vs-MTN hypothesis; 2) the bandwagon effect; and 3) the spread of democracy. The first suggests a complementarity between progress in multilateral trade talks and progress in regional trade agreements. The second suggests a very general 'demonstration effect' whereby nations sign FTAs because they see other nations signing them. The third stated that democratic countries are prone to sign FTA. These hypotheses could explain the wave like spread of regionalism. The key empirical lever that allows us to distinguish them from the contagion hypothesis is the extent to which trade ties connect the new FTA signers. The contagion hypothesis works on trade diversion, so the spread of FTAs should follow a pattern that is clearly related to the new signers' trade patterns. In particular, a pair of nations should be more likely to sign a new FTA, if either of them has recently signed FTAs with third nations that in which the pair's exporters are rivals.

\subsection{Literature: Empirical analysis of FTA formation}

Even the discussion about the determinants of FTA can be track back to Viner's contributions in the mid XX century, is in the early 1990s when become an important issue in International Trade. The focal question in this literature is: Why are countries eager to open markets bilaterally or regionally but reluctant to do so multilaterally? While trade policy scholars have proposed a number of explanations ${ }^{2}$, and some of these explanations have been formalized by theorists ${ }^{3}$, in the empirical side there is just few contributions. The Membership to FTA was typically taken as exogenous in empirical specifications, but recently researchers have started to view it as an endogenous phenomenon and have begun to explore its determinants.

The first systematic empirical study on the determinants of a FTA is Baier and Bergstrand (2004), which use worldwide data to estimate cross sectional linear probability models, stressing that economic factors seems to be enough to predict must of the agreements. In particular, they find that the likelihood of an FTA between a country pair is higher the closer they are, the more distant from the rest of the world, the larger and more similar their economic size are and the more different their labour ratios are (Heckscher-Ohlin trade).

Some previous empirical studies have already put emphasis in the "domino effect" as determinant of FTA, focusing in trade diversion as a key determinant in the willingness of membership to the European Union. A first attempt is Sapir (1997), which estimates year-by-year cross-section gravity models and finds that trade diversion tends to spike in a time pattern that explains tend to EU enlargements.

\footnotetext{
${ }^{1}$ See Baldwin $(1994,1997,2002,2006)$ for applications of it to European, Western Hemisphere and Asian domino effects.

2 Anderson and Blackhurst (1993), Krugman (1993), Bhagwati (1993), Whalley (1996), Lawrence (1996), Bergsten (1996), Panagariya (1996), inter alia.

${ }^{3}$ Grossman and Helpman (1995), Yi (1996), Ethier (1996), Bond and Syropoulos (1996), Yi (1996), Winters (1996), Levy (1997), Fernandez and Portes (1998), Krishna (1998), Freund (2000), Mclaren (2002), and Aghion, Antras and Helpman (2004).
} 
Baldwin and Rieder (2007) follow a similar strategy but estimating trade creation and diversion in a panel setting to then use the results for calculate the likelihood to become a EU member.

Some studies have focused in aspects beyond the economic determinants. Mansfield and Reinhardt (2003) offer a more political explanation, arguing that one of the main determinants of regional trade agreements are developments at the multilateral level, with difficulties in GATT/WTO negotiations prompt countries to engage in regionalism. Mansfield, Milner, and Rosendorff (2002) empirically find that pairs of democratic countries are more likely to form a FTA, a result confirmed by Wu (2004) that also claims that economic and trade uncertainty matter. After determining FTA that are effectively implemented, Holmes (2005) show evidence of "mercantile interests" in assuring export market access are a important determinants.

\subsection{Literature: Contagious crisis and policies}

Dungey et al. (2004) review the empirical models of contagion in macro crisis literature, classifying the methodologies in: latent factor; correlation analysis; vector autoregression (VAR); co-exceedance approach and probability models. Our work is mainly related with the latter approach, developed in the work by Eichengreen, Rose, and Wyplosz $(1995,1996)$, where a dichotomic measure of crisis is the dependent variable and the explanatory variable is the same measure for the rest of the countries, using trade and macro weights in order to analyse the channels of contagion. Using probit estimations they provide evidence of an increase in the probability of the occurrence of a crisis if there is a crisis somewhere else.

This approach is expanded by Novo (2004) to a multivariate framework in which multiple countries can be infected and their relative contagious influence is measured by a spatial weights matrix.

Some studies have extended the contagion analysis to economic policies. Elkins et al. (2004) argue that the diffusion of Bilateral Investments Treaties (BIT) is driven by international competition for FDI among potential host countries, then the likelihood of sign a BIT increase with the number of competing countries that have done so. Gassebner et al. (2008) examines if country's economic reforms are affected by the reforms adopted in the rest of the world. They find that cultural and geographical proximity tend to be factors in the contagion of reforms, but that trade links are not.

\section{DATA DESCRIPTION: FTA AND CONTAGION INDEX}

\subsection{Free Trade Agreements}

The phenomenon we are investigating is the signing of new FTA, so the 'left hand variable' is a digital variable reflecting it existence (unity if yes and zero if no). We use the recently available Preferential Trade Agreements Database from the Peterson Institute for International Economics and the World Trade Institute (WTI), constructed using the historical notifications of the date the agreements entered into force and their contemporary participants. This source is the most extensive and detailed currently available; it is more comprehensive than the WTO database which is based only on agreements notified to the institution. The database has 570 agreements recorded from 1948 to 2007; of these, 329 agreements were still force in 2007.

We limit the period of investigation to 2005 due to lack of comprehensive data on our 'right hand side' variables. 
Table 1 summarises the FTAs. Europe dominates the FTAs with a total of 224, almost half of them signed in the 90s. The source of Europe's dominance in these figures is well known. Starting from the formation of the EEC in the 1950s and EFTA in 1960, the engagement between these groups and the enlargement of the former created a large number of FTA as has the external FTA engagement of the two blocks. In the Americas, 154 agreements have been signed including NAFTA, MERCOSUR and numerous bilateral FTAs among their countries. The Former Soviet Bloc nations, that we report separately, subscribed to numerous agreements during the 90 s reaching a total of 124 in 2005 . The Middle East and North Africa have 83 deals, while Asia has 54. The least dynamic region is SubSaharan Africa with 'just' 41 agreements in total, half of them coming from before 1976.

Table 1: Evolution of signing of FTAs by region and time

\begin{tabular}{|l|l|l|l|l|l|l|l|l|}
\hline Period & $\begin{array}{l}\text { Sub- } \\
\text { Saharan } \\
\text { Africa }\end{array}$ & Americas & Asia & Europe & $\begin{array}{l}\text { Mideast and } \\
\text { North Africa }\end{array}$ & $\begin{array}{l}\text { Former } \\
\text { Soviet } \\
\text { bloc }\end{array}$ & World & $\begin{array}{l}\text { Country } \\
\text { pairs }\end{array}$ \\
\hline Before 1976 & 22 & 20 & 8 & 42 & 11 & 1 & 83 & 326 \\
$1976-1990$ & 4 & 42 & 8 & 14 & 10 & 6 & 66 & 221 \\
$1991-1999$ & 3 & 48 & 9 & 100 & 31 & 93 & 229 & 495 \\
$2000-2005$ & 12 & 44 & 29 & 68 & 31 & 24 & 159 & 236 \\
\hline Total & 41 & 154 & 54 & 224 & 83 & 124 & 570 & 1319 \\
\hline
\end{tabular}

Source: WTI Database. Asia includes East and South Asia and Oceania. Europe includes Turkey. In the regional disaggregation the agreements are computed more than one time when the subscribers belong to different regions.

Our unit of study is the country-pair formation of FTA, a number which has evolved as shown in the next-to-last column of the table. A cumulative total of 1319 country-pair trade deals are registered up to 2005 , but just 1134 are still in force or signed for later implementation. That means that around $17 \%$ of the pairs of countries are covered by some sort of trade agreement in the year 2005. Among these agreements, 65\% are classified as pure Free Trade Agreements (FTAs), and the others are partial scope agreements, currency unions and the like. Nevertheless, to avoid linguistic infelicities, we refer to all them as FTAs.

For our analysis we will use all types of registered agreements, either in force or signed, since our prior is that the contagion effect is produced at the moment the agreement is created. The idea is that the threat of trade diversion is as important as actual trade diversion. Nevertheless, in the robustness check section we show that the use of a stricter definition of FTA do not alter the main results. In Appendix 1 we present the total number of FTAs signed by each country in the sample used in our empirics. The agreements are reduced to a total of 782 in 2005 when the data is cleaned.

\subsection{Measure of contagion}

Following the probability model of contagious currency crisis, a key element of our empirical approach is a measure of "infection". But here is going to appear an important difference between contagion episodes in macro crisis and in the FTA formation: while the former are temporary events, the latter are, in most of the cases, a permanent condition. A consequence of this difference is that the measure we have to use is not just an addition over the infected countries, but also an accumulation over the time.

In the case of contagion come from the threat of trade diversion, or loss of export competitiveness, two elements must be considered. Firstly, the number of FTAs signed by other countries (the more the infected, the most likely to be tainted). Second, the relative distance to other countries subscribing FTAs 
(the closest to the infected, the most exposed to contagion). Considering this, we propose the following "Contagion Index":

$$
\text { Contagion }_{i j, t}=\sum_{s=1}^{t} \sum_{\substack{k=1 \\ k \neq i, j}}^{n} \text { Export_share }_{\mathrm{ik}, \mathrm{s}} * \mathrm{FTA}_{\mathrm{jk}, \mathrm{s}}
$$

where:

$$
\text { Export_sharslk. }=\text { shars of wporte of country it to sountry of the year the FTA wae sil gusd. }
$$

and

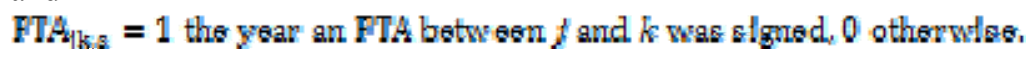

So in a given year $t$ the index for country $i$ with respect to $j$ is the accumulated sum of the FTAs signed by $j$ with the countries outside the pair in the past years, weighted by the commercial importance of the third countries to $i$, measured as the share of total exports to this country ${ }^{4}$.

This one-way contagion index can be better understood with the example illustrated inFigure 3. In 2005 Australia and Malaysia started the studies and negotiations to establish a FTA. Can this fact be related with a contagion effect? The contagion from Malaysia to Australia is measured by the cumulative of trade-weighted shares of Malaysia's FTAs. The trade weights are Australia's export shares to the third-nation with whom Malaysia has a deal, and to reduce simultaneity, the share is fixed at the time of FTA was signed. Ignoring the evolution of trade shares, it measures the share of Australian exports that go to nations with which Malaysia has an FTA.

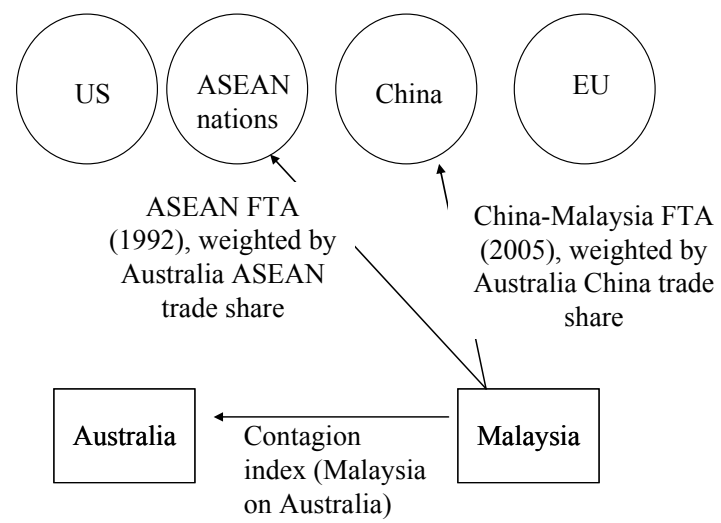

Figure 3: One-way contagion index

\footnotetext{
${ }^{4}$ The data on export shares is taken from COMTRADE. One possible concern with the total export shares as weight is the fact that some FTA cover just a number of industries, so only these sectors are threaded by the potential trade diversion, and only the export share of these industries might be used as the weight in the contagion indexes. Even this concern is true, our database do not have information on the specific sectors covered by the FTA. Moreover, our prior is that even one sector is not included in the original FTA, the fact that the agreement was signed create the threat that the sector can be included in the future.
} 
Up to 2005, Malaysia has signed three FTAs with countries in our sample: ASEAN Preferential Trading Arrangements with Indonesia, Philippines, Singapore and Thailand in $1978^{5}$; ASEAN expansion including Burma, Cambodia, Laos, and Vietnam in 1992; ASEAN-China Agreement on Trade in Goods in 2005. On the other hand, in the year the FTAs were established the export shares of Australia to the signers were $6 \%, 0.1 \%$ and $4 \%$, respectively. Then, the Contagion Index of Australia from Malaysia is the accumulation over the time of the shares, as shown in Figure 4.

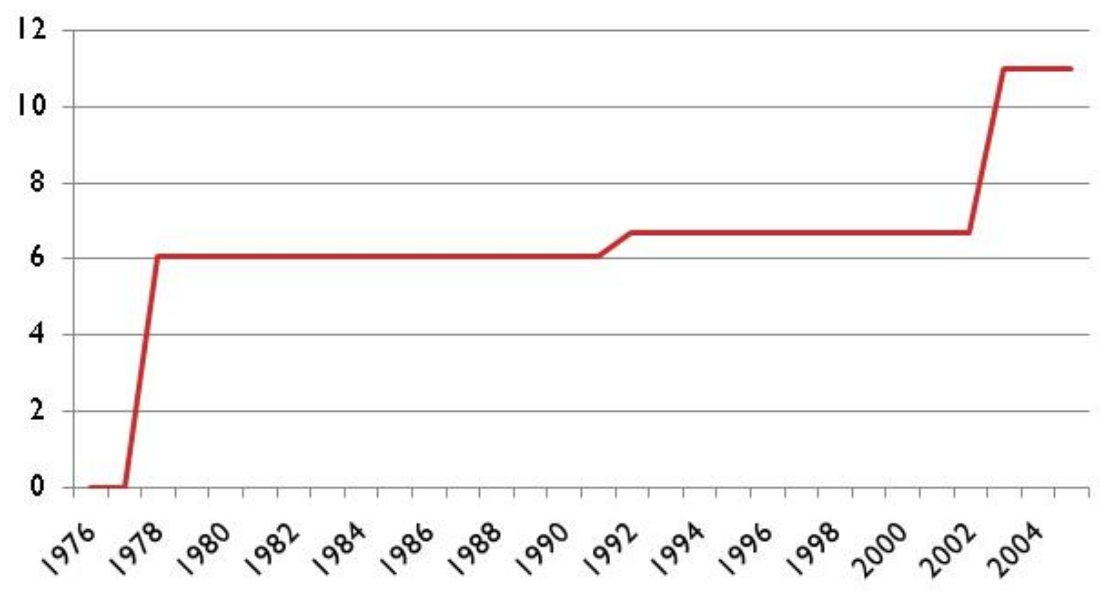

Figure 4: Contagion Index of Australia from Malaysia

Of course, it takes two to dance, when it comes to signing FTAs, so we must also consider the contagion of Australia on Malaysia. Considering the dyadic nature of the data, in the empirical exercises we do this in two ways: some specifications are with directed dyads, so two observations per country-pair are included for each year (one for the country as recipient and other as giver), and the Contagion Index is directly plugged. In the rest of the specifications, one observation per dyad is included, implying that a symmetric measure should be used. In this case, we take the two one-way Contagion Indexes for each country-pair and build three indicators ${ }^{6}$ : (1) the arithmetic average of the indexes for $i j$ and $j i$; (2) the maximum of these indexes, related with effect of the most infected country; (3) the minimum of these indexes, related with the decision of the less infected country. The average of the three contagion indicators by country in 2005 is summarized in Appendix 1.

There are some potential endogeneity problems since the index depends upon actual trade flows which are influenced by the matrix of FTAs. We address this in our robustness checks, where we show that using different samples and measures of export shares the results are unaffected.

\footnotetext{
${ }^{5}$ That actually was established as a Free Trade Area just in 1992, so in the stricter definition of the robustness check this year will be used instead of 1978 .

${ }^{6}$ In order to align the contagion indicators with the scale of other variables we will use in the regressions, the indicators are multiplied by 100 .
} 


\section{RESULTS}

\subsection{Cross-Section}

Our first approach is to study the cross sectional properties of the contagion indicators, that have to thought as the long-term or cumulative effect. Here we will start following the literature in the static determinants of the formation of FTAs between pairs of countries. The most important contribution in the area is the study by Baier and Bergstrand (2004, B\&B henceforth) that amply a qualitative choice model to show the main economic variables underlying the FTAs accumulated up to a giving year. The basic empirical model is:

$$
P(F T A=1)_{i f}=G\left(\beta_{0}+\beta X_{i t}\right)
$$

where the probability to sign a FTA will be determined by the standard normal cumulative distribution function of a linear specification, $\mathrm{G}\left({ }^{*}\right)$, that ensures the result lies between 0 and $1 . X_{i j}$ is a vector of time invariant explanatory variables related to the country-pair and $\beta$ the related coefficients. We expand this specification by introducing the contagion indicators to estimate models for the year 2005. Then, our model is the following:

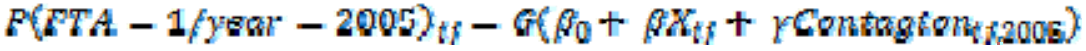

where Contagion $\mathrm{ij}_{\mathrm{j} 2005}$ is the accumulated value of one of the contagion indicators up to 2005 and $\gamma$ is the parameter of interest.

For the sake of comparability, we first estimate the results in a reduced sample similar to the one used by $\mathrm{B} \& \mathrm{~B}$ (and later expand the analysis to the entire database). The reduced sample is composed by 52 countries and 1303 country-pairs, of which 372 have a FTA in force or signed in 2005. This subsample has important advantages. With long series of export data available to build the contagion indexes for these countries, our results are not be driven by discontinuous declaration of data in exports or the creation/extinction of a country. Almost the full range of possible pairings are covered (the possible country-pairs are 52 time 51 divided by 2 , i.e. 1326).

In the first panel of Table 2 we present the result of the probit estimation of the model. The first column shows a very important fact: when just one explaining variable is included, "natural partners" measure with the inverse of the countries distance, a great deal of the FTAs can be predicted as showed in the Correct Classification Ratio $(\mathrm{CCR})^{8}$, with $86 \%$ of accuracy and a pseudo- $\mathrm{R}^{2}$ of 0.456 . Adding more economic and cultural determinants do little to improve the efficiency of the estimations. In column 2 a measure of remoteness from the rest of the world, the product and ratio of the logs of GDPs (proxies for economic size and its differences respectively) and the ratio capital/labour are included ${ }^{9}$, with just slightly improvements in accuracy. The determinants in column 2 are the same as in the final empirical specification of $\mathrm{B} \& \mathrm{~B}$, and we obtain similar signs, magnitudes and significance than them for

${ }^{7}$ In B\&B there are 54 countries and 1431 pairings, of which 286 have a PTA. The 2 countries that we miss are Iraq and Nigeria due to lack of updated data availability. In Table Appendix 1 the countries that integrate the reduced sample are identified.

${ }^{8}$ The ratio is built assigning 1 to the predicted probabilities over one half and 0 below and then comparing with the row data.

${ }^{9}$ All the definitions and sources are in Appendix 2. 
all the parameters, with the exception of the one related with the capital/labour ratio ${ }^{10}$. In column 3 we explore some shared cultural characteristics between the countries in the pair that could be important to determinant the existence FTAs, namely common language, a past colonial relationship and common colonizer (dropped by colinearity in this specification). B\&B disregard this type of determinants, but, in opposition, we find that common language has a positive and significant effect, and that slightly improve the efficiency of the model, a result confirmed in later exercises.

In the last columns of the first panel the values for the three contagion indicators for 2005 are included. In order to follow B\&B original specification, undirected dyads (one observation per dyad) are estimated, and the symmetric contagion indicators are used. Column 4 shows that the indicator that averages the country-pair contagion indexes has a positive and significant impact in the probability to sign a FTA, with an improvement of five percentage points in the pseudo- $\mathrm{R}^{2}$. The coefficients for contagion indicators for the maximum and minimum index, in columns 5 and 6 respectively, also are positive and significant, and increase significantly the goodness of fit with respect to the first specifications. Together, these results provide a first evidence of the relevance of contagion effect that should anyhow be taken with care, considering that the pseudo- $\mathrm{R}^{2}$ is a ratio of likelihoods with no direct interpretation, as also happen with the probit coefficients that just inform about sign and significance.

The second panel of the Table 2 shows the results of estimate the cross-sectional probability model for FTAs in the whole sample. Even we tried to have a sample as large as possible, some depurations must be performed. In order to properly compute the contagion indicators, enough information for the export shares should be available, so we drop countries with information of exports for less than 45 destinations. Also some countries are eliminated for lack of information in some of the other variables used in the estimation. After this cleaning process, we end up with a sample of 112 countries and 4661 pairings, of which 782 have a FTA. Column 7 shows that the sole variable "natural partners" is still enough to have a good prediction for the FTAs, as measured by the CCR, but has a lower goodness of fit that in the B\&B sample. When the other economic and cultural determinants are included (column 8) similar results that in the reduced sample are obtained, with the difference that now the capital/labour ratio is negative and significant, and the dummy for common colonizer is positive and significant. When contagion indicators are added (columns 9 to 11) a significant improvement in the goodness of fit is achieved, particularly in the case of the indicator for the minimum contagion in the pair. The three indicators are positive and significant.

In the last panel of the table we present results for the directed dyadic regression, implying that the number of observations are the double that in the undirected dyads specification. The direct Contagion Index is estimated, allowing for asymmetry in the effect. The structure of the errors in this specification is very particular, with blocks created for the interaction of the different members of the dyad with the rest of the countries that violate the homoskedastic assumption ${ }^{11}$. To obtain the correct specification for the errors, we use the correction proposed by Fafchamps and Gubert (2007). The results are similar to the obtained with the undirected dyads specification, with a positive and statistically significative Contagion Index.

${ }^{10}$ We use the same data of $\mathrm{B} \& \mathrm{~B}$ to measure this ratio, coming from Baier et al. (2000). The results related to this parameter are the only ones that change considerably in sign and significance with the different sample and model specifications we tried; in particular, most specifications give us negative and significant estimates for this variable.

${ }^{11}$ For further details, Fafchamps and Gubert (2007). 
Table 2: Cross Section Results

\begin{tabular}{|c|c|c|c|c|c|c|c|c|c|c|c|c|}
\hline \multirow[b]{3}{*}{ COEFFICIENT } & \multicolumn{6}{|c|}{ B\&B SAMPLE } & \multicolumn{5}{|c|}{ TOTAL SAMPLE } & \multirow{3}{*}{$\begin{array}{c}\text { DYADIC } \\
\text { REGRESSION } \\
\text { IN TOTAL } \\
\text { SAMPLE }\end{array}$} \\
\hline & (1) & (2) & (3) & (4) & (5) & (6) & (7) & (8) & (9) & (10) & (11) & \\
\hline & All FTA & All FTA & All FTA & All FTA & All FTA & All FTA & All FTA & All FTA & All FTA & All FTA & All FTA & \\
\hline contagion (average) & & & & $\begin{array}{c}0.0371 * * * \\
(0.0044)\end{array}$ & & & & & $\begin{array}{c}0.0227 * * * \\
(0.0020)\end{array}$ & & & \\
\hline contagion (max) & & & & & $\begin{array}{c}0.0319^{* * *} \\
(0.0028)\end{array}$ & & & & & $\begin{array}{c}0.0158^{* * *} \\
(0.0011)\end{array}$ & & \\
\hline contagion (min) & & & & & & $\begin{array}{c}0.0315^{* * *} \\
(0.0029)\end{array}$ & & & & & $\begin{array}{c}0.0315 * * * \\
(0.0016)\end{array}$ & \\
\hline Contagion Index & & & & & & & & & & & & $\begin{array}{c}0.0283 * * * \\
(0.0015)\end{array}$ \\
\hline natural & $\begin{array}{c}1.277 * * * \\
(0.0664)\end{array}$ & $\begin{array}{c}0.969 * * * \\
(0.0934)\end{array}$ & $\begin{array}{c}0.997 * * * \\
(0.0940)\end{array}$ & $\begin{array}{l}0.811 * * * \\
(0.0939)\end{array}$ & $\begin{array}{c}0.710^{* * *} \\
(0.0980)\end{array}$ & $\begin{array}{c}0.548 * * * \\
(0.0958)\end{array}$ & $\begin{array}{l}1.113 * * * \\
(0.0385)\end{array}$ & $\begin{array}{l}1.050 * * * \\
(0.0507)\end{array}$ & $\begin{array}{c}0.923 * * * \\
(0.0522)\end{array}$ & $\begin{array}{c}0.862 * * * \\
(0.0544)\end{array}$ & $\begin{array}{c}0.697 * * * \\
(0.0555)\end{array}$ & $\begin{array}{l}1.577 * * * \\
(0.1014)\end{array}$ \\
\hline remoteness & & $\begin{array}{c}0.0826^{* * *} \\
(0.0170)\end{array}$ & $\begin{array}{c}0.0696^{* * *} \\
(0.0176)\end{array}$ & $\begin{array}{c}0.0671 * * * \\
(0.0177)\end{array}$ & $\begin{array}{c}0.0739 * * * \\
(0.0187)\end{array}$ & $\begin{array}{c}0.0765^{* * *} \\
(0.0190)\end{array}$ & & $\begin{array}{c}0.0333 * * * \\
(0.0090)\end{array}$ & $\begin{array}{c}0.0332 * * * \\
(0.0093)\end{array}$ & $\begin{array}{c}0.0427 * * * \\
(0.0095)\end{array}$ & $\begin{array}{c}0.0415^{* * *} \\
(0.0101)\end{array}$ & $\begin{array}{c}0.0698 * * * \\
(0.0175)\end{array}$ \\
\hline product GDP & & $\begin{array}{c}0.116^{* * *} \\
(0.0187)\end{array}$ & $\begin{array}{c}0.143 * * * \\
(0.0209)\end{array}$ & $\begin{array}{c}0.133 * * * \\
(0.0221)\end{array}$ & $\begin{array}{c}0.0898^{* * *} \\
(0.0238)\end{array}$ & $\begin{array}{l}0.116^{* * *} \\
(0.0221)\end{array}$ & & $\begin{array}{c}0.159 * * * \\
(0.0118)\end{array}$ & $\begin{array}{c}0.147 * * * \\
(0.0126)\end{array}$ & $\begin{array}{c}0.134 * * * \\
(0.0129)\end{array}$ & $\begin{array}{c}0.0947 * * * \\
(0.0141)\end{array}$ & $\begin{array}{l}0.242 * * * \\
(0.0237)\end{array}$ \\
\hline ratio GDP & & $\begin{array}{c}-0.102 * * * \\
(0.0346)\end{array}$ & $\begin{array}{c}-0.106^{* * *} \\
(0.0342)\end{array}$ & $\begin{array}{l}-0.0272 \\
(0.0368)\end{array}$ & $\begin{array}{c}0.0485 \\
(0.0391)\end{array}$ & $\begin{array}{l}-0.00284 \\
(0.0372)\end{array}$ & & $\begin{array}{c}-0.0738 * * * \\
(0.0184)\end{array}$ & $\begin{array}{c}-0.0815^{* * *} \\
(0.0194)\end{array}$ & $\begin{array}{c}-0.0752 * * * \\
(0.0199)\end{array}$ & $\begin{array}{l}-0.0187 \\
(0.0206)\end{array}$ & $\begin{array}{c}-0.113 * * * \\
(0.0371)\end{array}$ \\
\hline ratio $\mathrm{K} / \mathrm{L}$ & & $\begin{array}{l}-0.0267 \\
(0.0649)\end{array}$ & $\begin{array}{l}-0.0143 \\
(0.0629)\end{array}$ & $\begin{array}{c}-0.105 \\
(0.0690)\end{array}$ & $\begin{array}{l}-0.0617 \\
(0.0753)\end{array}$ & $\begin{array}{l}-0.168^{* *} \\
(0.0765)\end{array}$ & & $\begin{array}{c}-0.0791 * * * \\
(0.0266)\end{array}$ & $\begin{array}{c}-0.101 * * * \\
(0.0286)\end{array}$ & $\begin{array}{c}-0.0926^{* * *} \\
(0.0296)\end{array}$ & $\begin{array}{c}-0.0808^{* *} \\
(0.0326)\end{array}$ & $\begin{array}{c}-0.150^{* * *} \\
(0.0562)\end{array}$ \\
\hline common language & & & $\begin{array}{c}0.430 * * * \\
(0.1335)\end{array}$ & $\begin{array}{l}0.739 * * * \\
(0.1374)\end{array}$ & $\begin{array}{c}0.984 * * * \\
(0.1696)\end{array}$ & $\begin{array}{c}0.862 * * * \\
(0.1307)\end{array}$ & & $\begin{array}{c}0.807 * * * \\
(0.0753)\end{array}$ & $\begin{array}{c}0.896 * * * \\
(0.0762)\end{array}$ & $\begin{array}{c}0.956^{* * *} \\
(0.0786)\end{array}$ & $\begin{array}{l}1.035 * * * \\
(0.0755)\end{array}$ & $\begin{array}{l}1.750 * * * \\
(0.1361)\end{array}$ \\
\hline colony & & & $\begin{array}{l}-0.00934 \\
(0.3081)\end{array}$ & $\begin{array}{c}-0.187 \\
(0.2845)\end{array}$ & $\begin{array}{c}-0.259 \\
(0.3248)\end{array}$ & $\begin{array}{c}-0.288 \\
(0.2797)\end{array}$ & & $\begin{array}{l}0.00821 \\
(0.1896)\end{array}$ & $\begin{array}{c}0.0107 \\
(0.1938)\end{array}$ & $\begin{array}{c}0.0453 \\
(0.2033)\end{array}$ & $\begin{array}{l}-0.0840 \\
(0.1904)\end{array}$ & $\begin{array}{c}0.0233 \\
(0.3527)\end{array}$ \\
\hline common colonizer & & & & & & & & $\begin{array}{l}0.327 * * * \\
(0.1002)\end{array}$ & $\begin{array}{c}0.413 * * * \\
(0.1013)\end{array}$ & $\begin{array}{c}0.366^{* * *} \\
(0.1061)\end{array}$ & $\begin{array}{l}0.260 * * \\
(0.1018)\end{array}$ & $\begin{array}{c}0.660^{* * *} \\
(0.1844)\end{array}$ \\
\hline Observations & 1303 & 1303 & 1303 & 1303 & 1303 & 1303 & 4661 & 4661 & 4661 & 4661 & 4661 & 9322 \\
\hline Countries & 52 & 52 & 52 & 52 & 52 & 52 & 112 & 112 & 112 & 112 & 112 & 112 \\
\hline CCR & 0.857 & 0.869 & 0.881 & 0.881 & 0.867 & 0.916 & 0.869 & 0.889 & 0.889 & 0.891 & 0.918 & \\
\hline Pseudo R2 & 0.456 & 0.485 & 0.492 & 0.536 & 0.612 & 0.588 & 0.349 & 0.427 & 0.456 & 0.478 & 0.559 & \\
\hline
\end{tabular}

Robust standard errors in parentheses

*** $\mathrm{p}<0.01,{ }^{* *} \mathrm{p}<0.05,{ }^{*} \mathrm{p}<0.1$ 


\subsection{Robustness checks for cross section}

In the estimations presented in the last section, the contagion indexes are defined in the way showed in Section 2, using as weights the export shares with a third country in the year the FTA is signed with it. Even this specification alleviates a great deal of the simultaneity problem presented in most of empirical specification that relates FTAs and partner trading relevance, since the export share of the countries in the pair is never present, still some endogeneity problems could be biasing the estimates.

The fact that a pair of countries has signed a FTA can affect the share of exports to third countries in different ways. The most obvious endogeneity is produced when a bloc is created, since in the same year a pair signs the agreement some of the main trading partners will be doing the same, then the exports shares to the members in the bloc will increase and the contagion index will be endogenous. To alleviate this problem we re-estimate the direct dyadic specifications in the last panel of Table $2^{12}$ dropping the country-pairs formed by founder members of one of three blocs: EU9 (the EU members before 1976), MERCOSUR and ASEAN. The first column of of Table 3 shows that basic results do not change in the new sample (control's parameters are not displayed).

Table 3: Robustness Checks for cross sectional results

\begin{tabular}{|c|c|c|c|c|c|}
\hline & $\begin{array}{c}(1) \\
\text { FTA } \\
\end{array}$ & $\begin{array}{c}(2) \\
\text { FTA } \\
\end{array}$ & $\begin{array}{r}(3) \\
\text { FTA } \\
\end{array}$ & $\begin{array}{r}(4) \\
\text { FTA } \\
\end{array}$ & $\begin{array}{c}(5) \\
\text { Pure FTA } \\
\end{array}$ \\
\hline Contagion Index No Blocks & $\begin{array}{c}0.0284 * * * \\
(0.0015)\end{array}$ & & & & \\
\hline Contagion Index Weights 1976 & & $\begin{array}{c}0.0382 * * * \\
(0.0027)\end{array}$ & & & \\
\hline Contagion Index Weights 1962 & & & $\begin{array}{c}0.0399 * * * \\
(0.0037)\end{array}$ & & \\
\hline Contagion Index Gravity & & & & $\begin{array}{c}0.0330 * * * \\
(0.0022)\end{array}$ & \\
\hline Contagion Index Pure FTA & & & & & $\begin{array}{c}0.0375 * * * \\
(0.0014)\end{array}$ \\
\hline Observations & 9234 & 4360 & 1578 & 9274 & 9322 \\
\hline Countries & 112 & 72 & 46 & 112 & 112 \\
\hline
\end{tabular}

Dyadic adjusted standard errors in parentheses. $* * * \mathrm{p}<0.01, * * \mathrm{p}<0.05,{ }^{*} \mathrm{p}<0.1$

Same controls as in the last panel of Table 2 are included but showed in the table.

But the effects of FTAs are more complex. As shown in the theoretical discussion of the domino effect, trade creation matters as well as trade diversion. Thus even trade shares of third countries that are not part of a bloc get affected when a FTA is signed, and, if eventually they joint later, the weights in the contagion index will contain an endogenous component. In order to definitively deal with this potential problem we take a more radical solution. We recalculate the contagion index, but using as weights the trade shares in the first year of the time series, 1976. The backdrop is a decrease in the dynamic nature of the indicators, but exogeneity is strengthened, especially since we drop all countrypairs with FTAs in this year. The regressions with is displayed in the second column of Table 3. This

${ }^{12}$ If same procedures are applied to the undirected dyads estimates, all the results of this subsection are the same. 
sample contains only 72 countries (for which we have data in the initial year) and 2180 pairs. The basic results hold.

We can even go more back in time, trying to eliminate any doubt due to possible endogeneity related with trade diversion of the FTAs of before 1976. We rebuild the indicators using the trade shares in the first year we could get data of exports, 1962, where the only agreement was the EU6, which pairings are eliminated of the specification. Column 3 of Table 3 shows the results of estimations that now get reduced to just 46 countries and 1578 observations. All main results hold.

A different approach to deal with the endogeneity is to estimate "potential" export shares instead of the observed in reality, so the weights is the latent trade relevance of the partner due to geographical, cultural and economic characteristics. The methodology to estimate the potential export shares is in two stages $^{13}$ : we first estimate a gravity equation where the dependent variable is the log of the actual exports volumes (measured in real US dollars) regressed against the log of the product of GDPs of the trade partners in a given year, including the dummy for FTA between them, country-pair fixed effects (that account for all common time invariant characteristics as distance, language, border, etc.) and year fixed effects (capturing common shocks). The second stage is to estimate the fitted export values to build the potential shares. Column 4 of Table 3 shows the results, with a no significant change in the value of the Contagion Index. Even this approach has several advantages in term of removing sources of endogeneity, like controlling for the change in trade shares due to agreements, we think that the real variable observed by the policy makers, actual trade shares, is a better weight to account for contagion effect.

A final robustness is related with the definition of FTA. In all the later calculations we use the broader definition of trade agreement available in our database, which include every kind of deals. But it's possible that the contagion just happen when the agreement is actually implemented and implies real concessions. In Column 5 of Table 3 we present re-estimates that use the contagion index built just with FTA in force and defined explicitly as Free Trade Agreements in the database, same thing for the dependent variable. $35 \%$ of the agreements are eliminated in these estimates, but the basic results hold.

\subsection{Panel specification}

Even the cross sectional results of the last section are important in order to state that a contagious effect is relevant in the determination of FTA formation, we now move to a panel specification were the dynamic nature of domino effect can be better analysed.

Estimate panel data with limited dependent variable represent several challenges. The problem of incidental parameters implies that the inconsistency in the estimation of fixed effects will be "transmitted" to estimation of parameters ${ }^{14}$. The bias in the estimation is very severe when $\mathrm{T}$ is short, but get smaller as $T$ increases if the number of cross sectional observations $(N)$ is sufficiently large (Greene 2004). Since we have the advantage that trade panels have both big $T$ and $N$, our first approach is to estimate the panel specification of the contagion hypothesis trough pooled regressions. We have $\mathrm{T}=30$ for the oldest countries in our sample, and an $\mathrm{N}$ of around three thousands country pairs (more for the latest years $)^{15}$. The specification is the following:

\footnotetext{
${ }^{13}$ For more details of this approach, Frankel and Romer (1999) and others.

${ }^{14}$ For more details, Baltagi (2005)

${ }^{15}$ Greene (2004) shows that, using Monte Carlo simulations, the bias of imposing fixed effects by brutal force in panels with limited dependent variable is around $7 \%$ when $\mathrm{T}=20$ and $\mathrm{N}=1000$.
} 


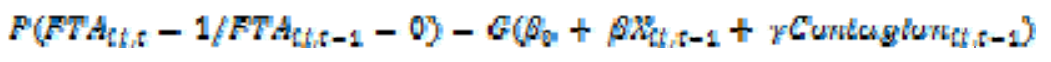

With the dependent variable been now the probability that a pair of countries sign a trade agreement in period $t$, conditional to the fact that such agreement did not exist in the previous period. This implies that the dyads with FTA before the beginning of the sample are not going to be included (notably EU founding members) and that the year after signing an FTA the dyad will disappear of the sample ${ }^{16}$.

Both the controls and the main variable of interest -the contagion index or its symmetrical measuresare expressed as one period lag in order to avoid endogeneity problems. This specification has several advantages since allows to include various political and economic controls that suffer of simultaneity in the cross sectional framework. Even more important, the use of lag values of the contagion index avoids the potential endogeneity problem that arises from the fact that the probability of signing an FTA is not independent of the signatures of FTA anywhere else in the same period, an issue that just can be properly addressed with spatial econometrics techniques in the cross-section ${ }^{17}$.

Since most of the specifications are going to be over the directed dyads (both observations in each dyad-year will be included), the structure of the errors is not homoskedastic. In order to correct for this fact, all the specification will cluster the standard errors at dyad level.

Another concern with this empirical specification is the related with the problem serial correlation: since observations are likely to be temporally related due to duration dependence in the data, the use of traditional probit or logit techniques represent problems. In order to solve this issue, we include natural cubic spline function of the numbers of years a dyad have been without a FTA, a solution proposed by Beck et al, (1998).

Some previous studies have already used similar panel specification to analyse the formation of FTA, and among those the most important is Mansfield and Reinhardt (2003, M\&R henceforth). As first exercise, we will use the same dataset used by M\&R to analyse how the contagion indexes behave in $\mathrm{it}^{18}$. The main goal of M\&R's work is to empirically test the hypothesis that developments in the multilateral trade system encourage the formation of FTA among GATT/WTO members, an idea supported by Krugman (1993) and Bhagwati (1993) among others. Particularly, they test that: (1) FTA are used as a way to gain bargaining power during multilateral trade rounds; (2) as the number of GATT/WTO members arise, the individual country power leverage within the system decrease inducing FTA; (3) countries involved in a GATT/WTO dispute will be more willing to sign FTA in order to enhance their leverage in the quarrel; and (4) a country losing a dispute will be more willing to form FTA that mitigate the negative impacts of the lost.

In the first column of Table 4 we reproduce M\&R results for the period 1950-1998 for the estimations in the directed dyads ${ }^{19}$. The parameters estimated for the four variables associated to the multilateral system events just described have all positive and significative signs, supporting the M\&R claim:

${ }^{16}$ One concern to this specification is that values different than zero are rare events in the dependent variable, implying possible loss of power and bias in the estimation. In order to address this problem, we re-estimate all the main regressions using the methodology proposed by King and Zeng (2001) to solve the problem, and all the main results do not change. These results are available upon request.

${ }^{17}$ See Egger and Larch (2007) for details in the solutions to the problem of interdependence of FTA membership.

${ }^{18}$ The dataset is available in Eric Reinhardt's web page: http://userwww.service.emory.edu/ erein/data/ and all the variables and sources are described in M\&R.

${ }^{19}$ When undirected dyads are estimated, the main results are unchanged. These results are available upon request. 
detrended number of GATT/WTO members; a dummy equal 1 if a trade round is ongoing in a given year; a dummy equal 1 if one country in the pair lost a dispute and a dummy equal 1 if the country was in a dispute.

Table 4: Dynamic Determinants of FTA in M\&R Dataset

\begin{tabular}{|c|c|c|c|c|c|c|}
\hline & $\begin{array}{c}(1) \\
\text { m\&r fta } \\
1950-98\end{array}$ & $\begin{array}{c}(2) \\
\mathrm{m} \& \mathrm{r} f \mathrm{fa} \\
1950-75\end{array}$ & $\begin{array}{c}(3) \\
\text { m\&r fta } \\
1976-98\end{array}$ & $\begin{array}{c}(4) \\
\text { m\&r fta } \\
1976-98\end{array}$ & $\begin{array}{c}(5) \\
\text { fta wti } \\
1976-98 \\
\end{array}$ & $\begin{array}{c}(6) \\
\text { fta wti } \\
1976-98 \\
\end{array}$ \\
\hline Contagion Index (t-1) & & & & $\begin{array}{c}0.0289 * * * \\
(0.0032)\end{array}$ & & $\begin{array}{c}0.0104 * * * \\
(0.0025)\end{array}$ \\
\hline WTO Members (t-1, detrended) & $\begin{array}{l}0.138 * * * \\
(0.0109)\end{array}$ & $\begin{array}{c}-0.0974 * * * \\
(0.0269)\end{array}$ & $\begin{array}{c}-0.134 * * * \\
(0.0459)\end{array}$ & $\begin{array}{c}-0.0724 * * \\
(0.0351)\end{array}$ & $\begin{array}{c}-0.143 * * * \\
(0.0438)\end{array}$ & $\begin{array}{c}-0.144 * * * \\
(0.0454)\end{array}$ \\
\hline WTO Round (t-1) & $\begin{array}{l}1.691 * * * \\
(0.1577)\end{array}$ & $\begin{array}{c}0.0351 \\
(0.1915)\end{array}$ & $\begin{array}{c}-1.196 * * \\
(0.5808)\end{array}$ & $\begin{array}{l}-0.971 * * \\
(0.4936)\end{array}$ & $\begin{array}{c}-2.053 * * * \\
(0.5447)\end{array}$ & $\begin{array}{c}-2.119 * * * \\
(0.5687)\end{array}$ \\
\hline WTO Dispute Lost (t-3) & $\begin{array}{l}1.438 * * * \\
(0.1210)\end{array}$ & $\begin{array}{l}1.944 * * * \\
(0.1621)\end{array}$ & $\begin{array}{l}1.218 * * * \\
(0.2155)\end{array}$ & $\begin{array}{l}1.198 * * * \\
(0.2137)\end{array}$ & $\begin{array}{l}0.380^{* *} \\
(0.1752)\end{array}$ & $\begin{array}{l}0.407 * * \\
(0.1768)\end{array}$ \\
\hline WTO Dispute With Third Party (t-1) & $\begin{array}{c}0.769 * * * \\
(0.1331)\end{array}$ & $\begin{array}{l}0.345^{* *} \\
(0.1595)\end{array}$ & $\begin{array}{c}0.704 * * * \\
(0.2016)\end{array}$ & $\begin{array}{c}0.287 \\
(0.2029)\end{array}$ & $\begin{array}{c}-0.304 \\
(0.1900)\end{array}$ & $\begin{array}{c}-0.295 \\
(0.1897)\end{array}$ \\
\hline Democracy $(\mathrm{t}-1)$ & $\begin{array}{c}0.0491 * * * \\
(0.0053)\end{array}$ & $\begin{array}{c}0.0562 * * * \\
(0.0060)\end{array}$ & $\begin{array}{c}0.205 * * * \\
(0.0254)\end{array}$ & $\begin{array}{c}0.168 * * * \\
(0.0197)\end{array}$ & $\begin{array}{c}0.0278 * * \\
(0.0114)\end{array}$ & $\begin{array}{c}0.0299 * * * \\
(0.0116)\end{array}$ \\
\hline Distance & $\begin{array}{c}-0.674 * * * \\
(0.0272)\end{array}$ & $\begin{array}{c}-0.650 * * * \\
(0.0349)\end{array}$ & $\begin{array}{c}-1.039 * * * \\
(0.0870)\end{array}$ & $\begin{array}{c}-0.982 * * * \\
(0.0827)\end{array}$ & $\begin{array}{c}-1.155^{* * *} \\
(0.0840)\end{array}$ & $\begin{array}{c}-1.166^{* * *} \\
(0.0844)\end{array}$ \\
\hline GDP $(t-1)$ & $\begin{array}{c}-0.148 * * * \\
(0.0559)\end{array}$ & $\begin{array}{c}0.0170 \\
(0.0794)\end{array}$ & $\begin{array}{l}-0.0944 \\
(0.0635)\end{array}$ & $\begin{array}{l}-0.240 * * \\
(0.1051)\end{array}$ & $\begin{array}{l}-0.0292 \\
(0.0712)\end{array}$ & $\begin{array}{l}-0.0380 \\
(0.0704)\end{array}$ \\
\hline GDP per capita (t-1) & $\begin{array}{c}0.0185^{* * *} \\
(0.0042)\end{array}$ & $\begin{array}{c}-0.0121^{* *} \\
(0.0056)\end{array}$ & $\begin{array}{c}0.0514 * * * \\
(0.0076)\end{array}$ & $\begin{array}{c}0.0353 * * * \\
(0.0067)\end{array}$ & $\begin{array}{l}0.00862 \\
(0.0055)\end{array}$ & $\begin{array}{l}0.00879 \\
(0.0054)\end{array}$ \\
\hline GDP growth $(\mathrm{t}-1)$ & $\begin{array}{c}-0.0339 * * * \\
(0.0091)\end{array}$ & $\begin{array}{l}0.00515 \\
(0.0101)\end{array}$ & $\begin{array}{c}-0.0599 * * * \\
(0.0146)\end{array}$ & $\begin{array}{c}-0.0735^{* * *} \\
(0.0138)\end{array}$ & $\begin{array}{c}-0.0517 * * * \\
(0.0105)\end{array}$ & $\begin{array}{c}-0.0497 * * * \\
(0.0105)\end{array}$ \\
\hline FTA density (t-1, centered) & $\begin{array}{c}-21.58^{* * *} \\
(2.2825)\end{array}$ & $\begin{array}{l}-127.5^{* * *} \\
(10.9597)\end{array}$ & $\begin{array}{c}-114.5 \\
(103.3323)\end{array}$ & $\begin{array}{c}-105.0 \\
(87.3383)\end{array}$ & $\begin{array}{l}-60.26^{* * *} \\
(13.6951)\end{array}$ & $\begin{array}{l}-61.16^{* * *} \\
(13.8966)\end{array}$ \\
\hline FTA density $^{2}(\mathrm{t}-1$, centered $)$ & $\begin{array}{l}-511.1 * * * \\
(67.0399)\end{array}$ & $\begin{array}{c}-64.44 \\
(66.0358)\end{array}$ & $\begin{array}{c}-1803 \\
(3826.5012)\end{array}$ & $\begin{array}{c}-1528 \\
(3478.6977)\end{array}$ & $\begin{array}{c}425.3^{*} \\
(226.3410)\end{array}$ & $\begin{array}{c}466.8^{* *} \\
(228.7370)\end{array}$ \\
\hline Trade Partner Coverage (t-1) & $\begin{array}{c}3.073 * * * \\
(0.1445)\end{array}$ & $\begin{array}{c}2.889 * * * \\
(0.2061)\end{array}$ & $\begin{array}{c}4.319 * * * \\
(0.3129)\end{array}$ & & $\begin{array}{c}0.944 * * * \\
(0.2053)\end{array}$ & \\
\hline Time Trend & $\begin{array}{c}-0.357^{* * *} \\
(0.0230) \\
\end{array}$ & $\begin{array}{l}1.218^{* * *} \\
(0.1501) \\
\end{array}$ & $\begin{array}{c}0.246 * * * \\
(0.0892)\end{array}$ & $\begin{array}{c}0.0644 \\
(0.0731) \\
\end{array}$ & $\begin{array}{c}0.414 * * * \\
(0.1291) \\
\end{array}$ & $\begin{array}{c}0.413 * * * \\
(0.1343) \\
\end{array}$ \\
\hline Observations & 242917 & 62038 & 180879 & 101433 & 96237 & 96237 \\
\hline Countries & 108 & 74 & 108 & 94 & 94 & 94 \\
\hline Pseudo $\mathrm{R}^{2}$ & 0.452 & 0.538 & 0.586 & 0.504 & 0.419 & 0.418 \\
\hline
\end{tabular}

Several other ideas related with the formation of FTA can be tested in this framework, including the main theories described in Section 2. The thesis that link the spread of democracy and free trade agreements seems to have support since the variable Democracy (built using the POLITY IV index) is positive and significative. The idea that smaller countries are more prone to FTA is stated by the negative sign in the parameter associated to GDP and that richer counties are more active in that sense by the positive sign associated to GDP per capita. The notion that FTA formation is more likely in 
economic downturns is backed by the negative sign in the parameter for GDP growth. Bandwagon effect is incorporated by M\&R using the proportion of the 10 main trade partners that already have an FTA ("Trade Partner Coverage" in Table 4), a variable that appear with a positive and significative sign. More than a simple "monkeys see, monkeys do" we think that this variable represents preliminary evidence of the contagion effect. Finally, FTA density (proportion of dyads with and FTA in a given year) and its squared value are incorporated, showing a decreasing return of the gains related to the agreements (the negative sign is because the variable is centered in 0 ).

In columns 2 and 3 of Table 4 we split the sample of the first column in two sub-periods: 1950-1975 and 1976-1998, in order to study if the results are not dependent to the chosen time span. The main changes are that now the parameter associated to WTO members is now negative and significative, same for WTO round in the second period (in the first is non signicative). GDP is not significative anymore, while GDP per capita is negative in the first period and growth is just statistically relevant in the second. This is first evidence that M\&R results are not robust to different specifications.

In column 4 we now introduce a lagged value of our contagion index in order to test the hypothesis that FTA are contagious. As expected, the parameter associated with the index is positive and significative, providing preliminary evidence that in the dynamics of the FTA formation the influence effects of the domino theory are relevant. In this specification we have to drop the "Trade Partner Coverage" variable, because of its high collinearity with the contagion index (the partial pairwise correlation is around $80 \%$ ), that demonstrate the previously stated idea that this variable must be considered as an alternative proxy for contagion ${ }^{20}$.

Up to now, the M\&R definition of FTA has been used as the dependent variable, a measure based in the WTO record. We now will use our definition of FTA as dependent variable, based in the data described in Section 3. While in M\&R 238 new FTA are registered between 1976 and 1998, in ours the number rises until 382, with and overlap in half of the M\&R registers (122).

In column 5 of Table 4 we reproduce the regression of column 3, but now having our FTA data in the right hand side. The only important changes are that dispute with a third party is not significant anymore (driven by the change in sample size) and that GDP per capita is not significant either.

In the last column we include again the contagion index, but now using our data for FTA formation as dependent variable, and the results supporting contagion effect hold.

We now turn into the analysis of the dynamics of FTA formation in the database that we built for this proposes, that covers the period 1976-2005 (The countries included in the sample are listed in Appendix 1). We updated the variables of the M\&R specification and add several more controls (all the detail about the variables and their sources are on Appendix 2. The variables related with trade disputes at WTO will be updated for future versions of the paper).

In the first column of Table 5 we replicate the specification of the last column of Table 4, but now for the new period and dataset. Is possible to observe that the main results hold, with the contagion index been positive, same for democracy, GDP is insignificant, GDP per capita positive and GDP growth negative. The multilateral variables are non significatives or with the wrong sign. At this respect, is important to note that in our sample $64 \%$ of the agreements were signed when a multilateral round was happening, a fact that give no indication of the multilateral hypothesis since the round cover $60 \%$ of the

${ }^{20}$ When the contagion index and "Trade Partner Coverage" variables are together in the regressions of column 4 and 6 of Table 4, just the former is significant, but just at 5\%, while the variables are separately significant at $1 \%$. The reason why we think that "Trade Partner Coverage" is contagion and not bandwagon effect is because there is an economic meaning (trade diversion) that drives the FTA decision, over simple imitation. 
period in the sample. More importantly, by far the years with more FTA are 1984, 1993, 1995, 1998 and 2000, of which just during the second a multilateral round was open.

Table 5: Dynamic Determinants of FTA

\begin{tabular}{|c|c|c|c|c|c|c|c|}
\hline & $\begin{array}{c}(1) \\
\text { new fta }\end{array}$ & $\begin{array}{c}(2) \\
\text { new fta }\end{array}$ & $\begin{array}{c}(3) \\
\text { new fta }\end{array}$ & $\begin{array}{c}(4) \\
\text { new fta }\end{array}$ & $\begin{array}{c}\text { (5) } \\
\text { new fta }\end{array}$ & $\begin{array}{c}(6) \\
\text { new pure fta }\end{array}$ & $\begin{array}{c}\text { (7) } \\
\text { new fta }\end{array}$ \\
\hline Contagion Index (t-1) & $\begin{array}{c}0.0205 * * * \\
(0.0018)\end{array}$ & $\begin{array}{c}0.0183 * * * \\
(0.0021)\end{array}$ & & & & & \\
\hline $\begin{array}{l}\text { Contagion Index } \\
\text { (weights '76, t-1) }\end{array}$ & & & $\begin{array}{c}0.0197 * * * \\
(0.0029)\end{array}$ & & & & \\
\hline $\begin{array}{l}\text { Contagion Index } \\
\text { (weights '62, t-1) }\end{array}$ & & & & $\begin{array}{c}0.0260 * * * \\
(0.0051)\end{array}$ & & & \\
\hline $\begin{array}{l}\text { Contagion Index } \\
\text { (weights gravity, t-1) }\end{array}$ & & & & & $\begin{array}{c}0.0219 * * * \\
(0.0032)\end{array}$ & & \\
\hline $\begin{array}{l}\text { Contagion Index (Pure } \\
\text { FTA, t-1) }\end{array}$ & & & & & & $\begin{array}{l}0.0210 * * * \\
(0.0025)\end{array}$ & \\
\hline $\begin{array}{l}\text { Contagion Index (with } \\
\text { share of } j \text { and } k, \mathrm{t}-1 \text { ) }\end{array}$ & & & & & & & $\begin{array}{c}0.0500^{* * * *} \\
(0.0022)\end{array}$ \\
\hline $\begin{array}{l}\text { WTO Members } \\
\text { (detrended, } \mathrm{t}-1 \text { ) }\end{array}$ & $\begin{array}{c}-0.104 * * * \\
(0.0265)\end{array}$ & $\begin{array}{c}-0.113 * * * \\
(0.0279)\end{array}$ & $\begin{array}{c}-0.133 * * * \\
(0.0307)\end{array}$ & $\begin{array}{c}-0.0471 \\
(0.0401)\end{array}$ & $\begin{array}{c}-0.115^{* * *} \\
(0.0280)\end{array}$ & $\begin{array}{c}-0.238 * * * \\
(0.0324)\end{array}$ & $\begin{array}{c}-0.128 * * * \\
(0.0273)\end{array}$ \\
\hline WTO Round (t-1) & $\begin{array}{l}-0.327 \\
(0.2086)\end{array}$ & $\begin{array}{c}-0.348 \\
(0.2173)\end{array}$ & $\begin{array}{c}-0.382 \\
(0.2906)\end{array}$ & $\begin{array}{l}-1.281 * \\
(0.6657)\end{array}$ & $\begin{array}{c}-0.339 \\
(0.2179)\end{array}$ & $\begin{array}{c}-0.437 \\
(0.3328)\end{array}$ & $\begin{array}{l}-0.483^{* *} \\
(0.2303)\end{array}$ \\
\hline Democracy $(\mathrm{t}-1)$ & $\begin{array}{c}0.0381 * * * \\
(0.0108)\end{array}$ & & & & & & \\
\hline Political Distance (t-1) & & $\begin{array}{c}-0.0691 * * * \\
(0.0130)\end{array}$ & $\begin{array}{c}-0.0676^{* * *} \\
(0.0161)\end{array}$ & $\begin{array}{l}-0.0138 \\
(0.0241)\end{array}$ & $\begin{array}{c}-0.0682 * * * \\
(0.0132)\end{array}$ & $\begin{array}{c}-0.0668 * * * \\
(0.0140)\end{array}$ & $\begin{array}{c}-0.0686^{* * *} \\
(0.0140)\end{array}$ \\
\hline Geographical Distance & $\begin{array}{c}-1.045 * * * \\
(0.0752)\end{array}$ & $\begin{array}{c}-1.092 * * * \\
(0.0955)\end{array}$ & $\begin{array}{c}-0.922 * * * \\
(0.1281)\end{array}$ & $\begin{array}{c}-0.953 * * * \\
(0.1998)\end{array}$ & $\begin{array}{c}-1.162 * * * \\
(0.0957)\end{array}$ & $\begin{array}{c}-1.237 * * * \\
(0.1133)\end{array}$ & $\begin{array}{c}-0.727 * * * \\
(0.1051)\end{array}$ \\
\hline GDP (t-1) & $\begin{array}{l}-0.0665 \\
(0.0404)\end{array}$ & $\begin{array}{l}-0.0823^{*} \\
(0.0500)\end{array}$ & $\begin{array}{c}-0.147 * * * \\
(0.0525)\end{array}$ & $\begin{array}{l}-0.169^{*} \\
(0.0902)\end{array}$ & $\begin{array}{l}-0.117 * * \\
(0.0548)\end{array}$ & $\begin{array}{l}-0.0927 \\
(0.0572)\end{array}$ & $\begin{array}{r}-0.00183 \\
(0.0470)\end{array}$ \\
\hline GDP per capita (t-1) & $\begin{array}{c}0.0389 * * * \\
(0.0051)\end{array}$ & $\begin{array}{c}0.0332 * * * \\
(0.0054)\end{array}$ & $\begin{array}{c}0.0372 * * * \\
(0.0060)\end{array}$ & $\begin{array}{c}0.0443 * * * \\
(0.0098)\end{array}$ & $\begin{array}{c}0.0319 * * * \\
(0.0054)\end{array}$ & $\begin{array}{l}0.0418 * * * \\
(0.0060)\end{array}$ & $\begin{array}{l}-0.00445 \\
(0.0060)\end{array}$ \\
\hline GDP Growth (t-1) & $\begin{array}{c}-0.0420 * * * \\
(0.0093)\end{array}$ & $\begin{array}{c}-0.0441 * * * \\
(0.0107)\end{array}$ & $\begin{array}{c}-0.0381 * * * \\
(0.0118)\end{array}$ & $\begin{array}{l}0.00170 \\
(0.0197)\end{array}$ & $\begin{array}{c}-0.0473 * * * \\
(0.0110)\end{array}$ & $\begin{array}{c}-0.0644 * * * \\
(0.0130)\end{array}$ & $\begin{array}{c}-0.0634 * * * \\
(0.0124)\end{array}$ \\
\hline $\begin{array}{l}\text { Trade with county } \\
\text { partner over GDP (t-1) }\end{array}$ & & $\begin{array}{l}0.0586 * * * \\
(0.0157)\end{array}$ & $\begin{array}{c}0.0468 * * * \\
(0.0158)\end{array}$ & $\begin{array}{c}0.0861 * * * \\
(0.0233)\end{array}$ & $\begin{array}{c}0.0562 * * * \\
(0.0159)\end{array}$ & $\begin{array}{l}0.0626^{* * *} \\
(0.0162)\end{array}$ & $\begin{array}{c}0.0659 * * * \\
(0.0140)\end{array}$ \\
\hline FTA Expertise & & $\begin{array}{l}0.333 * * * \\
(0.1230) \\
\end{array}$ & $\begin{array}{l}0.316^{* *} \\
(0.1289) \\
\end{array}$ & $\begin{array}{c}0.438 \\
(0.2739) \\
\end{array}$ & $\begin{array}{l}0.308 * * \\
(0.1211) \\
\end{array}$ & $\begin{array}{c}0.812 * * * \\
(0.1574) \\
\end{array}$ & $\begin{array}{c}-0.156 \\
(0.1375) \\
\end{array}$ \\
\hline Observations & 115799 & 115799 & 80079 & 28092 & 115273 & 115799 & 115799 \\
\hline Countries & 112 & 112 & 72 & 46 & 112 & 112 & 112 \\
\hline Pseudo $\mathrm{R}^{2}$ & 0.238 & 0.297 & 0.347 & 0.358 & 0.292 & 0.454 & 0.366 \\
\hline
\end{tabular}

In Table 2 we add several variables to the specification. First, we test the idea that in terms of political system, more than having a pure democratic regime, what matters in order to form an FTA with another country is the "Political distance", meaning the difference between the regimens in both countries, that we measure as the absolute value of the difference in the POLITY IV index for the countries in the pair. Some descriptive statistics can help to understand our prior. In the M\&R database, for the period 19761998, just 4\% of the countries signing FTA were autocracies (with POLITY IV measure less than zero), while in our database the proportion rise to one quarter. The reasons that explain the disparity are 
related with sample composition (countries like Algeria, Jordan and Syria, that are classified as autocracies at the moment of sign various FTA are not in M\&R database); the lack of information in M\&R record for FTA (agreements signed the year countries like Morocco, Singapore and South Africa were autocracies are not registered); some of these FTA involving autocracies were signed after 1998 (65 in total). At the same time, while the average political distance for the countries in our database is 7.64 (7.99 in M\&R database), it get reduced to 4.4 (2.94 in M\&R) for countries that sign an FTA.

In column 2 of Table 5 we show that the measure of political distance is negative and significative, a result that hold for different specifications, and that gives support to our idea. The measure of Democracy is deleted in this specification (and the following), because of it collinearity with measure of political distance, but when was included was usually insignificant (and the results for political distance where unchanged). Finally, is worthy to note that eliminating the measure of democracy also alleviate the collinearity issue of this variable and GDP per capita that comes from the "modernisation hypothesis" (richer countries tend to be more democratic).

Another important variable that we add to the new specification is the bilateral trade between the signings countries. This is with no doubt one of the main determinants of the FTA formation, but the obvious endogeneity in cross sectional specifications have implied that several studies do not incorporate it (some of the M\&R specifications included trade, but the limited number of observations was restrictive for their sample size). We incorporate this variable as the total bilateral trade (exports plus imports) over recipient country GDP. As expected, the estimated parameter is positive and significative.

It is very likely that countries that already have signed several FTA will be keep doing that, both because they have learn how to do it and because the threat of new FTA in terms of import completion are likely to be less. We include a variable denominated "FTA expertise", a dummy takes value 1 if the country has signed more than 8 agreements ${ }^{21}$. As expected this variable is positive and significative.

Other controls that are included but not showed in Table 5 are: all the controls of B\&B specification, a dummy equal one if one of the countries in the dyad is on transition from communism, a dummy for military alliance (that was never significative) and the FTA density.

In columns 3 to 6 we include the same robustness measures of contagion indexes, obtaining always results that support the contagion hypothesis and with control variables that have same results and interpretation as in the basic specification.

In column 7 we add an additional robustness measure. Up to now, in the indexes we were considering the trade relevance of the countries in the dyad, but not the importance of the third member with which the "contagiant" country (country $j$ in the contagion index equation) is signing agreements. In order to take this in account, we re-estimate the indexes, but now weighting the agreement with the third country by the exports shares of $j$ to $k$. We can see that main results hold, and the parameter associated to the index is bigger than in previous estimations, indicating that accounting for the commercial relevance of the third countries signing an FTA increase the level of contagion.

Up to now, in the analysis of dynamic of FTA some crucial time invariant controls have been used as controls in the panel regression -notably country's distance-, but no dyad fixed effects have been used (the inclusion of fixed effects by "brutal force" in this case will imply the addition of around four

${ }^{21}$ Our first approach was to include the sum of FTA that a country has signed up to a given year, and its quadratic value, but collinearity problems arose from this measure. The threshold of 8 FTA was chosen because this is the median value of the sample, and because taken values in its vicinity leaves the results unchanged, while having values over 12 or 13 changed the other results in unexpected ways (and increase the correlation of the dummy with GDP per capita, democracy and the time trend). 
thousand dummies). One solution to alleviate the bias problem in panels with limited dependent variable is to estimate conditional likelihood functions with minimal sufficient statistics for the fixed effects. Chamberlain (1980) proposed a conditional logit model that in our case will take the following form:

$$
L=\prod_{i=1}^{N} \operatorname{Pr}\left(F T A_{i 1}, \ldots, F T A_{i T} / \sum_{t=1}^{T} F T A_{i t}\right)
$$

When the conditional probability is different than 1, the logit function do not involve the fixed effects parameters and conventional Maximum Likelihood estimation can be perform. Then conditional logits will provide unbiased estimations of the parameters, but just for the sub-sample of dyads that switch status during the observed period, that is those that subscribe an FTA between 1977 and 2005.

Table 6: Dynamic Determinants of FTA, Conditional Logit Estimates (Dyads Fixed Effects)

\begin{tabular}{|c|c|c|c|c|c|c|}
\hline & $\begin{array}{c}(1) \\
\text { All FTA }\end{array}$ & $\begin{array}{c}(2) \\
\text { All FTA } \\
\end{array}$ & $\begin{array}{c}(3) \\
\text { All FTA }\end{array}$ & $\begin{array}{c}(4) \\
\text { All FTA }\end{array}$ & $\begin{array}{c}(5) \\
\text { All FTA } \\
\end{array}$ & $\begin{array}{c}(6) \\
\text { Pure FTA }\end{array}$ \\
\hline Contagion (average, $\mathrm{t}-1$ ) & $\begin{array}{l}0.257 * * \\
(0.1027)\end{array}$ & & & & & \\
\hline Contagion (max, t-1) & & $\begin{array}{c}0.265 * * * \\
(0.0383)\end{array}$ & & & & \\
\hline Contagion (min, $\mathrm{t}-1$ ) & & & $\begin{array}{c}0.102 \\
(0.0657)\end{array}$ & & & \\
\hline Contagion exports '76 (average, t-1) & & & & $\begin{array}{c}0.198^{*} \\
(0.1154)\end{array}$ & & \\
\hline Contagion gravity (average, $\mathrm{t}-1$ ) & & & & & $\begin{array}{l}0.353 * * \\
(0.1755)\end{array}$ & \\
\hline Contagion pure FTA (average, t-1) & & & & & & $\begin{array}{c}0.222 * * * \\
(0.0316)\end{array}$ \\
\hline WTO Members ( $\mathrm{t}-1$, detrended) & $\begin{array}{c}-0.0498^{* *} \\
(0.0250)\end{array}$ & $\begin{array}{l}-0.0374 \\
(0.0257)\end{array}$ & $\begin{array}{l}-0.0322 \\
(0.0248)\end{array}$ & $\begin{array}{c}-0.0675^{* *} \\
(0.0281)\end{array}$ & $\begin{array}{c}-0.0518 * * \\
(0.0247)\end{array}$ & $\begin{array}{c}0.0246 \\
(0.0162)\end{array}$ \\
\hline WTO Round (t-1) & $\begin{array}{l}-0.468 * * \\
(0.1950)\end{array}$ & $\begin{array}{l}-0.273 * \\
(0.1537)\end{array}$ & $\begin{array}{c}-0.110 \\
(0.1368)\end{array}$ & $\begin{array}{c}-0.812^{* * *} \\
(0.1857)\end{array}$ & $\begin{array}{l}-0.347 * * \\
(0.1675)\end{array}$ & $\begin{array}{l}-0.0597 \\
(0.1767)\end{array}$ \\
\hline Political Distance (t-1) & $\begin{array}{l}-0.0178 \\
(0.0523)\end{array}$ & $\begin{array}{l}-0.0743 \\
(0.0543)\end{array}$ & $\begin{array}{l}-0.0553 \\
(0.0632)\end{array}$ & $\begin{array}{c}0.0130 \\
(0.0771)\end{array}$ & $\begin{array}{l}-0.0403 \\
(0.0567)\end{array}$ & $\begin{array}{c}0.0566 \\
(0.0547)\end{array}$ \\
\hline GDP product $(\mathrm{t}-1)$ & $\begin{array}{c}0.0121^{*} \\
(0.0067)\end{array}$ & $\begin{array}{c}0.0143 * \\
(0.0083)\end{array}$ & $\begin{array}{c}0.0224 * * \\
(0.0093)\end{array}$ & $\begin{array}{c}0.0200 * * \\
(0.0092)\end{array}$ & $\begin{array}{l}0.0104 * \\
(0.0059)\end{array}$ & $\begin{array}{c}0.00196 * \\
(0.0010)\end{array}$ \\
\hline Observations & 7332 & 7332 & 7332 & 5847 & 7268 & 8580 \\
\hline Dyads & 401 & 401 & 401 & 255 & 397 & 456 \\
\hline Pseudo R2 & 0.769 & 0.750 & 0.731 & 0.809 & 0.744 & 0.770 \\
\hline
\end{tabular}

Standard errors clustered over dyads in parentheses. ${ }^{* *} \mathrm{p}<0.01,{ }^{* *} \mathrm{p}<0.05,{ }^{*} \mathrm{p}<0.1$. Six duration dependence splines and a time trend are included but no showed in the table. 
The dependent variable is now again the FTA status binary variable, with value 0 before the agreement was registered and 1 afterwards, so some of the economic variables in the previous specification are endogenous and will not be included. Here we will prefer a undirected dyads specification, so the symmetric measures of contagion will be tested.

In the three first columns of Table 6 we show the results of the conditional logit estimates for the undirected dyads for the symmetric indicators of contagion. Of those, the average and maximum indicator are positive and significative, but the one for minimum contagion is not significative. We control for the multilateral variables, that again have the opposite sign that predicted; for political distance, that in this case have the right sign but is not statically relevant; and for the product of the GDP of countries in the dyad, that is positive and significative (at $5 \%$ ).

The last three columns of Table 6 perform the same previous robustness checks -now just for the averaged contagion indicator- and the basic results supporting contagion effect hold.

\section{CONCLUDING REMARKS}

This preliminary draft presents evidence that contagion may be important in explaining the spread of regionalism. Our index of contagion is aimed at capturing the extent to which a nation can 'catch' the FTA 'bug' by trading with nations that sign many FTAs, especially those with important third-country trading partners. Two critiques of the current state of the work have been made clear to us. First, the contagion index is somewhat ad hoc. The solutions to this are to provide a firmer theoretical basis for it, and to try many other variants. Second, even we implemented several checks to solve potential endogeneity problems with the weights in the indexes, we have not done the same for the FTAs signed by third countries, something that requires the use of recent developments in spatial econometric techniques.

In a subsequent version, we plan to redress these shortcomings.

\section{REFERENCES}

Aghion, P., P. Antràs and E. Helpman (2004). Negotiating Free Trade. NBER Working Paper no.10721, National Bureau of Economic Research, Cambridge, MA.

Anderson, K and Blackhurst, R. (1993), 'Introduction and summary', in K.Anderson and R.Blackhurst (eds.), Regional integration and the global trading system, (London: Harvester-Wheatsheaf).

Baier, S.L., and J.H. Bergstrand (2003). Economic Determinants of Free Trade Agreements. Journal of International Economics, vol. 64, pp. 29-63.

Baier, Scott L., Jeffrey H. Bergstrand \& Peter Egger (2007). “The new regionalism: causes and consequences," Économie internationale 109 (2007), p. 9-29.

Baldwin, Richard (1993), 'A domino theory of regionalism', NBER WP 4465. Published as: Baldwin, Richard E. (1995), 'The domino theory of regionalism', in Baldwin, Haaparanta and Kiander (eds.), Expanding membership of the European Union (Cambridge: Cambridge University Press). Republished as Chapter 23 (pp 479-502) in J. Bhagwati, P. Krishna and A. Panagariya (1999), Trading blocs: Alternative approaches to analyzing preferential trade agreements, Cambridge: MIT Press.

Baldwin, Richard (1994). Towards an integrated Europe, CEPR (London).

Baldwin, Richard (2000). "Regulatory Protectionism, Developing Nations and a Two-Tier World Trading System," Brookings Trade Forum, S. Collins and D. Rodrik (es), The Brookings Institution, Washington DC, pp 237-293, 2000. 
Baldwin, Richard E. (1995), 'The domino theory of regionalism', in Baldwin, Haaparanta and Kiander (eds.), Expanding membership of the European Union (Cambridge: CambridgeUniversity Press).

Baldwin, Richard E. (1997). "The causes of regionalism," The World Economy, Vol. 20, No, 7, pp 865-888, 1997.

Baldwin, Richard, and Charles Wyplosz, (2006). The Economics of European Integration, McGrawHill, 2nd Edition.

Baldwin, Richard and Roland Rieder (2007). Test of Endogenous Trade Bloc Formation Theory on

EU Data. CEPR Discussion Paper No. DP6389

Baltagi, B.H. (2005): Econometric Analysis of Panel Data, Third edition.

Beck, Nathaniel, Jonathan Katz, and Richard Tucker (1998). Taking Time Seriously: Time-SeriesCross-Section Analysis with a Binary Dependent Variable. American Journal of Political Science. Vol. 42, No. 4, pp. 1260-1288..

Bergsten, F. (1996), 'Competitive liberalisation and global free trade: A vision for the early 21 st century,' (Washington DC: Institute for International Economics).

Bergsten, F. (1996), 'Open Regionalism,' (Washington: Institute for International Economics).

Bergstrand, J. and S. Baier "Economic Determinants of Free Trade Agreements," Journal of International Economics, Vol 64, No. 1, October 2004, $29-63$.

Bhagwati, J (1993), 'Regionalism and multilateralism: An overview,' in Anderson, K and Blackhurst, R. (eds), Regional integration and the global trading system, (London: Harvester-Wheatsheaf).

Bhagwati, Jagdish (2008). Termites in the Trading System: How Preferential Agreements Undermine Free Trade. Oxford University Press.

Bond, Eric W., and Constantinos Syropolous (1996). "The size of trading blocs: Market power and world welfare effects," Journal of International Economics, Vol. 40, pp. 411-437.

Chamberlain, Gary (1980). Analysis of Covariance with Qualitative Data. Review of Economic Studies, Vol. XLVII(1), No. 146

Cheng, I., and H. Wall (2005), Controlling for Heterogeneity in Gravity Models of Trade and Integration. Federal Reserve Bank of St. Louis Review, vol. 87, pp. 49-63.

Dorrucci. E., S. Firpo, M. Fratzscher, and FP Mongelli (2003)."What Lessons for Latin America from European Institutional and Economic Integration?" in: P. van der Haegen and J. Viñals (eds.), Regional Integration in Europe and Latin America - Monetary and Financial Aspects. Ashgate, Aldershot. pp. 171-218.

Dungey, Mardi, Renée Fry, Brenda González-Hermosillo, and Vance Martin (2004).

"Empirical Modeling of Contagion: A Review of Methodologies," IMF Working Paper, WP/04/78.

Gassebner, Martin, Gaston, Noel and Lamla, Michael J. (2008). The Inverse Effect: Are Economic Reforms Contagious?. KOF Working Papers No. 187

Greene, William (2004). The Behaviour of the Maximum Likelihood Estimator of Limited Dependent Variable Models in the Presence of Fixed Effects. Econometrics Journal, Vol. 7, No. 1, pp. 98-119.

Egger, Peter and Mario Larch, "Interdependent Preferential Trade Agreement Memberships: An Empirical Analysis", Journal of International Economics, 2008, forthcoming.

Elkins, Zachary, Andrew Guzman and Beth Simmons (2004). Competing for Capital: The Diffusion of Investment, 1960-2000. UC Berkeley Public Law Research Paper No. 578961.

Eichengreen, B., Rose, A. K. \& Wyplosz, C. (1995). Exchange market mayhem: The antecedentsand aftermath of speculative attacks. Economic Policy 21, 249-312.

Eichengreen, Barry J., Rose, Andrew K. and Wyplosz, Charles (1996) Contagious Currency Crises. NBER Working Paper No. W5681. 
Fafchamps, Marcel and Gubert, Flore (2007). "The formation of risk sharing networks," Journal of Development Economics, Elsevier, vol. 83(2), pages 326-350, July.

Fernandez, Raquel and Portes, Jonathan, 1998. "Returns to Regionalism: An Analysis of Nontraditional Gains from Regional Trade Agreements," World Bank Economic Review, Oxford University Press, vol. 12(2), pages 197-220, May.

Frankel, Jeffrey and David Romer (1999), "Does trade cause growth?" American Economic Review vol 89, 3, 379-399

Freund, C. (2000) Different Paths to Free Trade: The Gains from Regionalism*. Quarterly Journal of Economics 115:4, 1317-1341.

Grossman, G. and E. Helpman (1995). “The Politics of Free-Trade Agreements," American Economic Review 85 (1995b):667-690.

Holmes, Tammy (2005). What Drives Regional Trade Agreements that Work? HEI Working Paper, No. 07/2005, Graduate Institute of International Studies, Geneva.

Hufbauer, G. (1989). Background Paper for The Free Trade Debate, Reports of the 20th Century Fund Task Force on the Future of American Trade Policy, Priority Press, New York.

Katz, E. (2001). Bias in Conditional and Unconditional Fixed Effects Logit Estimation. Political Analysis, vol. 9, pp. 379-384.

King, Gary, and Langche Zeng (2001). Explaining Rare Events in International Relations. International Organization 55 (3):693-715.

Krishna, P. (1998). "Regionalism and Multilateralism: A Political Economy Approach,” Quarterly Journal of Economics, February 1998, Vol. 113, No. 1, Pages 227-250.

Krugman, P. (1991a). "The move toward free trade zones," Economic Review, Federal Reserve Bank of Kansas City, issue Nov, pages 5-25.

Krugman P. (1991b). "Is Bilateralism Bad?," in Helpman and Razin.(eds) International Trade and Trade Policy, Cambridge MA, MIT Press.

Krugman, Paul (1993), 'Regionalism versus multilateralism: Analytic notes', in De Melo, J. and Panagariya, A. (eds), New dimensions in regional integration, (Cambridge: CambridgeUniversity Press for CEPR).

L. Neal, D. Barbezat (1998). "The Economics of European Union and the Economies of Europe." Oxford University Press, 1998.

Lawrence, R. (1996), Regionalism, multilateralism and deeper integration, (Washington: Brookings Institute).

Levy, Philip, 1997, “A political-economic analysis of free-trade agreements,” American Economic Review, Vol. 87, pp. 506-519.

Mansfield, Edward, Helen Milner and B. Peter Rosendorff (2002). Replication, Realism, and Robustness: Analyzing Political Regimes and International Trade. American Political Science Review, 2002, 96(1):167-69.

Mansfield, E.D. and E. Reinhardt (2003). Multilateral Determinants of Regionalism: The Effects of GATT/WTO on the Formation of Preferential Trade Agreements. International Organization, vol. 57, pp. 829-862.

Maskus, K. and J.S. Wilson (eds) (2001). Quantifying the impact of technical barriers to trade: Can it be done?, Michigan University Press, Ann Arbor.

Mclaren, J. (2002) A Theory of Insidious Regionalism. Quarterly Journal of Economics 117:2, 571608.

Novo, A. (2004). Contagious Currency Crises: A Spatial Probit Approach. Banco de Portugal

Working Paper. 
Panagariya (1996), 'APEC and the United States,' CIES DP, (University of Adelaide).

Rieder, R. (2006). Playing Dominoes in Europe: An Empirical Analysis of the Domino Theory for the EU, 1962-2004. HEI Working Paper, No. 11/2006, Graduate Institute of International Studies, Geneva. Sapir, A. (1997),'Domino effects in Western European Trade, 1960-1992,' CEPR DP (London). Published as 'Domino effects in Western European regional trade, 1960-92', European Journal of Political Economy, Vol 17: 386, 2001.

Viner, J. (1950). The Customs Union Issue. Carnegie Endowment for International Peace, New York. Whalley, J. (1993), 'Regional trade arrangements in North America: CUSTA and NAFTA,' in De

Melo, J. and Panagariya, A. (eds), New dimensions in regional integration, (Cambridge:

CambridgeUniversity Press for CEPR).

Whalley, J. (1996), 'Why do countries seek regional trade agreements?', NBER WP 5552 (Cambridge MA)

Winters, A. (1996), 'Regionalism versus multilateralism,' World Bank PolicyResearch Working Paper 1687, (Washington).

Wu, J.P. (2004). Measuring and Explaining Levels of Regional Economic Integration. ZEI Working Paper B12/2004, Centre for European Integration Studies, Bonn.

Yi, S. (1996), 'Endogenous formation of customs unions under imperfect competition: Open regionalism is good,' Journal of International Economics, 41, 151-175. 
APPENDIX 1: COUNTRIES IN THE SAMPLE

\begin{tabular}{|c|c|c|c|c|c|c|c|}
\hline \multirow{2}{*}{ Country } & \multirow{2}{*}{$\begin{array}{r}\text { Obs. } \\
(2005)\end{array}$} & \multirow{2}{*}{$\begin{array}{l}\text { Obs. } \\
\text { (panel) }\end{array}$} & \multirow{2}{*}{$\begin{array}{l}\text { First } \\
\text { Obs. }\end{array}$} & \multirow{2}{*}{$\begin{array}{l}\text { FTAs } \\
(2005)\end{array}$} & \multicolumn{3}{|c|}{ Contagion Indicators (mean 2005) } \\
\hline & & & & & Average & Max & Min \\
\hline TOTAL & 4661 & 134733 & & 782 & & & \\
\hline Albania & 57 & 484 & 1998 & 3 & 18.03 & 45.07 & 1.27 \\
\hline Algeria* & 83 & 2492 & 1976 & 27 & 19.44 & 53.46 & 23.05 \\
\hline Argentina* & 102 & 3287 & 1976 & 10 & 6.36 & 22.67 & 2.87 \\
\hline Armenia & 55 & 723 & 1993 & 9 & 11.54 & 27.37 & 9.12 \\
\hline Australia* & 106 & 3823 & 1976 & 7 & 11.27 & 25.76 & 6.82 \\
\hline Austria & 111 & 3774 & 1976 & 34 & 26.69 & 57.65 & 22.23 \\
\hline Azerbaijan & 68 & 585 & 1998 & 13 & 13.47 & 32.32 & 10.07 \\
\hline Bangladesh & 98 & 3110 & 1976 & 6 & 7.81 & 21.83 & 2.2 \\
\hline Belarus & 88 & 909 & 1997 & 11 & 11.44 & 31.18 & 7.85 \\
\hline Belgium* & 111 & 1258 & 1997 & 36 & 23.56 & 50.36 & 1.94 \\
\hline Bolivia* & 72 & 2147 & 1976 & 10 & 4.99 & 19.9 & 3.54 \\
\hline Brazil* & 110 & 3794 & 1976 & 11 & 4.9 & 18.64 & 1.75 \\
\hline Bulgaria* & 95 & 2386 & 1980 & 23 & 14.05 & 48.66 & 22.39 \\
\hline Burkina Faso & 49 & 1637 & 1976 & 4 & 13.21 & 30.98 & 0.89 \\
\hline Cambodia & 54 & 453 & 1998 & 6 & 8.98 & 23.16 & 3.53 \\
\hline Canada* & 110 & 3775 & 1976 & 7 & 9.08 & 22.68 & 4.01 \\
\hline $\mathrm{CAF}$ & 44 & 1563 & 1976 & 1 & 21.42 & 50.92 & 0.04 \\
\hline Chad & 37 & 1083 & 1976 & 1 & 15.25 & 41.23 & 0.04 \\
\hline Chile* & 92 & 2738 & 1976 & 30 & 27 & 65.29 & 20.59 \\
\hline China & 111 & 3795 & 1976 & 12 & 4.15 & 15.33 & 3.18 \\
\hline Colombia* & 92 & 3161 & 1976 & 19 & 6.6 & 21.25 & 3.21 \\
\hline Costa Rica* & 73 & 2574 & 1976 & 12 & 6.23 & 22.51 & 3.27 \\
\hline Cyprus & 94 & 2974 & 1976 & 22 & 20.71 & 49.22 & 24.2 \\
\hline Czech R.* & 110 & 1551 & 1993 & 24 & 13.06 & 49.77 & 20.77 \\
\hline Denmark* & 111 & 3921 & 1976 & 36 & 27.78 & 58.65 & 22.71 \\
\hline Ecuador* & 79 & 2319 & 1976 & 10 & 4.37 & 16.05 & 3.55 \\
\hline Egypt* & 100 & 3136 & 1976 & 33 & 21.57 & 51.23 & 20.81 \\
\hline El Salvador* & 70 & 2060 & 1976 & 9 & 5.56 & 18.38 & 2.49 \\
\hline Estonia & 87 & 1349 & 1993 & 22 & 20.44 & 57.19 & 30.21 \\
\hline Fiji & 45 & 1861 & 1976 & 3 & 13.24 & 29.54 & 1.83 \\
\hline Finland & 108 & 3736 & 1976 & 32 & 27.42 & 57.45 & 24.39 \\
\hline France* & 111 & 3942 & 1976 & 36 & 24.47 & 52.51 & 20.86 \\
\hline Gabon & 59 & 1835 & 1976 & 0 & 15.51 & 34.58 & 0.01 \\
\hline Gambia & 53 & 1560 & 1976 & 3 & 17.69 & 42.82 & 0.46 \\
\hline Georgia & 61 & 866 & 1992 & 11 & 19.59 & 49.63 & 8.89 \\
\hline Germany* & 111 & 3960 & 1976 & 36 & 23.31 & 50.96 & 19.92 \\
\hline Ghana & 73 & 2535 & 1976 & 6 & 10.72 & 29.64 & 0.32 \\
\hline
\end{tabular}




\begin{tabular}{|l|rrrrrrr|} 
Greece* & 109 & 3693 & 1976 & 8 & 21.13 & 49.38 & 18.95 \\
Guatemala* & 71 & 2323 & 1976 & 8 & 5.64 & 17.93 & 2.1 \\
Guinea & 57 & 1640 & 1976 & 4 & 15.89 & 39.89 & 0.36 \\
Guinea-Bissau & 30 & 1027 & 1976 & 0 & 14.3 & 30.53 & 0 \\
Guyana & 50 & 1983 & 1976 & 4 & 9.84 & 26.27 & 1.7 \\
Haiti & 55 & 1937 & 1976 & 2 & 6.2 & 17.64 & 0.38 \\
Honduras* & 66 & 2223 & 1976 & 8 & 5.05 & 19.53 & 1.66 \\
Hong Kong* & 109 & 3768 & 1976 & 1 & 5.71 & 17.9 & 1.63 \\
Hungary* & 107 & 3071 & 1976 & 24 & 12.5 & 50 & 21.72 \\
India & 110 & 3748 & 1976 & 9 & 6.71 & 19.15 & 3.06 \\
Indonesia* & 110 & 3375 & 1976 & 6 & 4.11 & 11.7 & 2.58 \\
Iran* & 76 & 2449 & 1976 & 7 & 7.89 & 26.15 & 2.04 \\
Ireland* & 109 & 3783 & 1976 & 36 & 27.92 & 60.13 & 23.61 \\
Israel & 97 & 2754 & 1976 & 22 & 22.91 & 69.04 & 17.05 \\
Italy* & 111 & 3936 & 1976 & 36 & 25.05 & 53.52 & 21.17 \\
Jamaica & 69 & 2683 & 1976 & 6 & 7.29 & 23.73 & 1.27 \\
Japan* & 111 & 3917 & 1976 & 2 & 1.93 & 12.54 & 1.55 \\
Jordan & 86 & 2491 & 1976 & 24 & 21.25 & 66.3 & 16.98 \\
Kazakhstan & 77 & 998 & 1994 & 14 & 14.95 & 36.6 & 8.86 \\
\hline & & & & & & \\
\hline
\end{tabular}

\begin{tabular}{|c|c|c|c|c|c|c|c|}
\hline \multirow{2}{*}{ Country } & \multirow{2}{*}{$\begin{array}{r}\text { Obs. } \\
(2005) \\
\end{array}$} & \multirow{2}{*}{$\begin{array}{c}\text { Obs. } \\
\text { (panel) }\end{array}$} & \multirow{2}{*}{$\begin{array}{l}\text { First } \\
\text { Obs. }\end{array}$} & \multirow{2}{*}{$\begin{array}{c}\text { FTAs } \\
(2005) \\
\end{array}$} & \multicolumn{3}{|c|}{ Contagion Indicators (mean 2005) } \\
\hline & & & & & Average & Max & Min \\
\hline Kenya & 74 & 2595 & 1976 & 6 & 9.18 & 24.65 & 1.74 \\
\hline Korea, South.* & 109 & 3556 & 1976 & 5 & 4.85 & 13.95 & 1.98 \\
\hline Kyrqyz R. & 59 & 730 & 1994 & 14 & 12.11 & 29.58 & 13.27 \\
\hline Latvia & 83 & 1221 & 1992 & 22 & 20.37 & 55.9 & 31.44 \\
\hline Lithuania & 83 & 1187 & 1992 & 22 & 20.77 & 55.18 & 33.13 \\
\hline Madagascar & 61 & 2178 & 1976 & 2 & 12.58 & 34.71 & 1.31 \\
\hline Malawi & 60 & 1851 & 1976 & 7 & 13.62 & 35.55 & 1.57 \\
\hline Malaysia & 111 & 3655 & 1976 & 6 & 5.58 & 15.17 & 2.56 \\
\hline Mali & 54 & 1632 & 1976 & 4 & 11.58 & 28.41 & 0.81 \\
\hline Mexico* & 85 & 2884 & 1976 & 35 & 21.96 & 69.96 & 9.72 \\
\hline Moldova & 59 & 750 & 1995 & 13 & 18.08 & 42.92 & 11.87 \\
\hline Morocco & 77 & 2799 & 1976 & 21 & 19.68 & 53.04 & 27.83 \\
\hline Mozambique & 52 & 1692 & 1976 & 4 & 15.8 & 36.12 & 1.3 \\
\hline Nepal & 47 & 1320 & 1976 & 4 & 7.19 & 24.33 & 1.73 \\
\hline Netherlands* & 111 & 3927 & 1976 & 36 & 26.11 & 57.33 & 22.53 \\
\hline New Zealand & 96 & 3576 & 1976 & 6 & 5.29 & 17.49 & 2.83 \\
\hline Nicaragua* & 66 & 1949 & 1976 & 8 & 7.22 & 17.95 & 2.37 \\
\hline Niger & 55 & 1608 & 1976 & 4 & 17.53 & 44.52 & 0.36 \\
\hline Norway* & 108 & 3790 & 1976 & 24 & 25.32 & 55.33 & 21.83 \\
\hline
\end{tabular}




\begin{tabular}{|c|c|c|c|c|c|c|c|}
\hline Pakistan & 108 & 3554 & 1976 & 13 & 6.87 & 19.67 & 3.05 \\
\hline Panama* & 79 & 2491 & 1976 & 7 & 5.19 & 20.72 & 1.06 \\
\hline Papua N. G. & 48 & 1793 & 1976 & 3 & 10.32 & 22.89 & 1.81 \\
\hline Paraguay* & 62 & 1969 & 1976 & 10 & 9.7 & 25.65 & 3.96 \\
\hline Peru* & 86 & 2818 & 1976 & 10 & 5.91 & 20.44 & 2.71 \\
\hline Philippines* & 95 & 3312 & 1976 & 6 & 5.94 & 16.7 & 2.69 \\
\hline Poland* & 109 & 3342 & 1976 & 24 & 13.19 & 51.51 & 23.17 \\
\hline Portugal* & 111 & 3719 & 1976 & 34 & 26.69 & 58.19 & 22.57 \\
\hline Romania & 99 & 1534 & 1976 & 23 & 13.27 & 48.97 & 23.2 \\
\hline Russia & 104 & 977 & 1998 & 11 & 8.99 & 22.89 & 2.49 \\
\hline Sierra Leone & 47 & 1696 & 1976 & 3 & 15.53 & 38.85 & 0.42 \\
\hline Singapore* & 98 & 3308 & 1976 & 14 & 8.22 & 33.59 & 9.31 \\
\hline Slovak R. & 104 & 1572 & 1993 & 24 & 13.65 & 51.8 & 20.88 \\
\hline South Africa* & 107 & 2837 & 1976 & 17 & 18.32 & 40.73 & 17.63 \\
\hline Spain* & 111 & 3869 & 1976 & 34 & 25.03 & 54.65 & 21.26 \\
\hline Sri Lanka & 86 & 2923 & 1976 & 6 & 7.67 & 21.5 & 2.53 \\
\hline Sweden* & 110 & 3840 & 1976 & 34 & 26.22 & 55.82 & 21.43 \\
\hline Switzerland* & 111 & 3858 & 1976 & 24 & 24.79 & 53.06 & 19.83 \\
\hline Syria & 68 & 2145 & 1976 & 14 & 18.32 & 49.84 & 23.69 \\
\hline Tajikistan & 53 & 436 & 1998 & 12 & 12.75 & 33.06 & 10.04 \\
\hline Tanzania & 71 & 2246 & 1976 & 6 & 10.6 & 27.06 & 2.37 \\
\hline Thailand* & 110 & 3640 & 1976 & 9 & 6.65 & 18.49 & 3.56 \\
\hline Togo & 60 & 1915 & 1976 & 6 & 15.01 & 34.42 & 0.55 \\
\hline TrinidadTobago & 74 & 2590 & 1976 & 6 & 4.42 & 14.02 & 1.42 \\
\hline Tunisia & 92 & 2964 & 1976 & 22 & 14.96 & 54.32 & 22.39 \\
\hline Turkey* & 110 & 3350 & 1976 & 27 & 24.62 & 52.87 & 22.07 \\
\hline Turkmenistan & 60 & 503 & 1998 & 14 & 10.77 & 27.81 & 9.82 \\
\hline Uganda & 53 & 1652 & 1976 & 5 & 11.85 & 34.74 & 1.97 \\
\hline Ukraine & 79 & 1020 & 1993 & 11 & 14.87 & 34.9 & 7.98 \\
\hline $\mathrm{UK}^{*}$ & 111 & 3986 & 1976 & 36 & 23.59 & 50.21 & 17.97 \\
\hline USA* & 111 & 1964 & 1976 & 16 & 2.38 & 17.66 & 3.31 \\
\hline Uruguay* & 83 & 2721 & 1976 & 14 & 8.21 & 24.5 & 3.35 \\
\hline Uzbekistan & 58 & 481 & 1998 & 15 & 12.71 & 30.78 & 11.76 \\
\hline Venezuela* & 73 & 2520 & 1976 & 2 & 5.54 & 16.74 & 3.06 \\
\hline Vietnam & 101 & 921 & 1998 & 3 & 5.66 & 15.08 & 0 \\
\hline Yemen & 68 & 1136 & 1991 & 10 & 7.67 & 26.02 & 3.04 \\
\hline Zambia & 62 & 2009 & 1976 & 0 & 12.83 & 28.54 & 1.82 \\
\hline
\end{tabular}

*Countries that belong to the B\&B sample. 


\section{APPENDIX 2: DATA DESCRIPTION}

\begin{tabular}{|c|c|}
\hline Distance & Rose (2004). \\
\hline Remoteness & $\begin{array}{l}\text { As defined by Baier and Bergstran (2004): } \\
\qquad \text { REMOTE }_{i j}=\operatorname{DCONT}_{i j} \\
\qquad \times\left\{\frac{\left[\log \left(\sum_{k=1, k \neq j}^{N} \text { Distance }_{i k} / N-1\right)+\log \left(\sum_{k=1, k \neq i}^{N} \text { Distance }_{j k} / N-1\right)\right]}{2}\right\} \\
\text { With DCONT dummy for i and j same continent, tanking from the World Bank's regions } \\
\text { classification. }\end{array}$ \\
\hline $\begin{array}{l}\text { GDP initial ratio } \\
\text { and product }\end{array}$ & $\begin{array}{l}\text { To calculate the product and ratio of the GDP (logs) we use data from the World Bank's } \\
\text { World Development Indicators (WDI). For each country we use the oldest available data, } \\
\text { starting in } 1960 \text { for old countries and the year of creation for new countries (in some } \\
\text { exceptions the data just start later). }\end{array}$ \\
\hline $\begin{array}{l}\text { capital/labour } \\
\text { ratio }\end{array}$ & $\begin{array}{l}\text { Taken from Baier, S.L., Dwyer, G., Tamura, R., 2000. We use the oldest data available for } \\
\text { each country. }\end{array}$ \\
\hline $\begin{array}{l}\text { Common } \\
\text { language }\end{array}$ & dummy for Common Language, Rose (2004). \\
\hline $\begin{array}{l}\text { Common } \\
\text { colonizer }\end{array}$ & Dummy for Common Colonizer after 1945, Rose (2004). \\
\hline Colony & Dummy for pairs ever in Colonial Relationship, Rose (2004). \\
\hline All FTA & $\begin{array}{l}\text { We use the newly built database available at the World Trade Institute (WTI). The data is } \\
\text { based on historical notifications of the date the agreements entered into force and their } \\
\text { contemporary participants. For more details: Hufbauer and Schott (2007) }\end{array}$ \\
\hline Export Shares & $\begin{array}{l}\text { UN Comtrade database (using the World Integrated Trade Solution of the World Bank), at } \\
\text { the 1-digit Standard International Trade Classification (SITC) level. Whenever a country } \\
\text { did not report data on exports, we use the pairid image of import from the partner. }\end{array}$ \\
\hline $\begin{array}{l}\text { GDP, GDP } \\
\text { growth, GDP } \\
\text { per capita }\end{array}$ & The data is taken from the World Bank's World Development Indicators (WDI). \\
\hline Democracy & $\begin{array}{l}\text { Captures this regime authority spectrum on a } 21 \text {-point scale ranging from -10 (hereditary } \\
\text { monarchy) to }+10 \text { (consolidated democracy). The data comes from the Polity IV project, } \\
\text { which publicly available data can be found at } \\
\text { http://www.systemicpeace.org/polity/polity4.htm }\end{array}$ \\
\hline $\begin{array}{l}\text { Trade with } \\
\text { county partner } \\
\text { over GDP }\end{array}$ & $\begin{array}{l}\text { UN Comtrade database (using the World Integrated Trade Solution of the World Bank), at } \\
\text { the 1-digit Standard International Trade Classification (SITC) level. }\end{array}$ \\
\hline $\begin{array}{l}\text { Military } \\
\text { Alliance }\end{array}$ & $\begin{array}{l}\text { A dummy taken value one for any positive record in the variable "formal alliances" in } \\
\text { Correlates of War database: http://www.correlatesofwar.org Since the variable is just } \\
\text { available up to } 2000 \text {, we assumed that the values of the last year were the same for the } \\
\text { missing period 2001-2004. }\end{array}$ \\
\hline $\begin{array}{l}\text { Transition from } \\
\text { communism }\end{array}$ & $\begin{array}{l}\text { We update the variable existent in M\&R database, incorporating former Soviet republics } \\
\text { and other countries not included in their sample. }\end{array}$ \\
\hline
\end{tabular}

